\title{
Performance of ANN in Predicting Internal Bonding of Cement Particleboard Manufactured from Giant Reed and Bagasse
}

\section{Primjena umjetne neuronske mreže u predviđanju čvrstoće na raslojavanje cementne iverice proizvedene od divovske trske i ostataka od prerade šećerne trske}

\author{
Original scientific paper • Izvorni znanstveni rad \\ Received-prispjelo: 9. 4. 2020. \\ Accepted-prihvaćeno: 25. 4. 2021. \\ UDK: $630 * 861.061 ; 630 * 863.21$ \\ https://doi.org/10.5552/drvind.2021.2018
}

\begin{abstract}
The present article investigates the microstructure of the cement matrices and the products of cement hydration by means of scanning electron microscopy, Fourier transform infrared spectroscopy and X-Ray diffraction. Then, the internal bonding strength (IB) is measured for the mixtures containing various amounts of nanosilica (NS), reed and bagasse particles. Finally, an Artificial Neural Network (ANN) is trained to reproduce these experimental results. The results show that the hardened cement paste including NS features the highest level of $C-S-H$. However, it has a lower level of $C-S$-H polymerization if reed or bagasse particles are applied. A relatively new dense microstructural degree is considered in the cement pastes containing NS, and a lower agglomeration is observed in the samples including reed or bagasse particles with NS. According to the microstructural analysis, the addition of NS to the samples containing reed or bagasse particles increases the unhydrated amount of $C_{2} S$ and $C_{3} S$ in the cement paste due to the decrease in the water needed for fully hydrated cement grains through portlandite ( $\left.\mathrm{Ca}(\mathrm{OH})_{2}\right), \mathrm{C}-\mathrm{S}-\mathrm{H}$ and ettringite increase. Besides, it is shown that the ANN prediction model is a useful, reliable and quite effective tool for modeling IB of cement-bonded particleboard (CBPB). It is indicated that the mean absolute percentage errors (MAPE) are $1.98 \%$ and $1.45 \%$ in the prediction of the IB values for the training and testing datasets, respectively. The determination coefficients $\left(R^{2}\right)$ of the training and testing data sets are 0.972 and 0.997 in the prediction of the bonding strength by $A N N$, respectively.
\end{abstract}

Keywords: cement-bonded particleboard; nanosilica; internal bonding; hydration; ANN

SAŽETAK •U radu se opisuje istraživanje mikrostrukture cementnih matrica i proizvoda hidratacije cementa uz pomoć pretražnoga elektronskog mikroskopa, Fourierove transformirane infracrvene spektroskopije i rendgenske difrakcije. Pritom je izmjerena i čvrstoća na raslojavanje (IB) za smjese koje sadržavaju različite količine čestica nanosilike (NS), trske i ostataka od prerade šećerne trske. Na kraju su uz pomoć umjetne neuronske mreže (ANN)

\footnotetext{
Authors are researchers at Shahid Beheshti University, Faculty of New technologies Engineering, Department of BioSystems, Tehran, Iran. ${ }^{2}$ Author is researcher at University of Zabol, Faculty of Natural Resources, Department of Wood and Paper Science and Technology, Zabol, Iran.
} 
reproducirani eksperimentalni podatci. Rezultati su pokazali da otvrdnuta cementna pasta s nanosilikom ima najvišu razinu C-S-H. Međutim, ako se rabe čestice trske ili ostataka od prerade šećerne trske, cementna pasta ima niži stupanj polimerizacije C-S-H. Detaljno je analiziran relativno nov stupanj gustoće mikrostrukture cementne paste koja sadržava nanosiliku, pri čemu su uočene i manje nakupine u uzorcima koji su, osim nanosilike, sadržavali i čestice trske ili ostataka od njezine prerade. Prema analizi mikrostrukture, dodatkom nanosilike uzorcima koji sadržavaju čestice trske ili ostataka od prerade šećerne trske povećava se nehidratizirana količina $C_{2} S$ i $C_{3} S$ u cementnoj pasti zbog smanjenja vode potrebne za potpunu hidratizaciju cementnih zrna putem portlandita $\left(\mathrm{Ca}(\mathrm{OH})_{2}\right)$ te povećanjem $\mathrm{C}-\mathrm{S}$-H i etringita. Osim toga, pokazalo se da je ANN model predviđanja koristan, pouzdan $i$ vrlo učinkovit alat za modeliranje čvrstoće cementne iverice na raslojavanje. Srednja apsolutna pogreška (MAPE) u predviđanju čvrstoće na raslojavanje za eksperimentalne i izmjerene skupove podataka iznosi 1,98\%, odnosno 1,45\%. Koeficijenti korelacije $R^{2}$ eksperimentalnih i izmjerenih skupina podataka u predviđanju čvrstoće na raslojavanje uz pomoć ANN modela iznose 0,972 odnosno 0,997.

Ključne riječi: cementna iverica; nanosilika; čvrstoća na raslojavanje; hidratacija; ANN

\section{INTRODUCTION}

\section{UVOD}

Mineral-bonded particleboards are panel products manufactured from the compressed particles of the wood or non-wood materials and a mineral binder such as cement. Among these panels, cement-bonded particleboards are well known and are applied in different components of the final industrial products. The increasing population and demands for wood-based composite materials have encouraged the researchers to study the application of the non-wood-based biomass in different composites. Annual plant and lignocellulosic waste materials can be substituted for wood to produce agro-based panels. Nowadays, more than 30 plants are used as renewable materials in various composed-productions around the world (Bektas et al., 2005). Therefore, it seems that substitution of raw materials such as agricultural waste will play an important role in the composite production industries such as particleboards in the future (Nemli et al., 2009). One of the lignocellulosic renewable biomasses is reed (Arundo donax) stalks. This species is known as a weedy and invasive plant in several countries (Quinn and Holt, 2008) and is considered as one of the 100 world's most aggressive species (Lowe et al., 2000). In addition, since this species is a fast renewable alternative, it can meet the demand for biomass production via cultivation of $A$. donaxon in a wide scale. However, using this material is accompanied by drawbacks that can strongly affect the properties of the lignocellulosic-based composite materials, including the adverse effects of certain extractives during cement hardening, undefined standard method to assess the compatibility of these materials with cement, etc.

In order to improve the compatibility between cement and lignocellulosic materials and cementbonded particleboard properties, researchers studied the effect of many variables, including particle size, different kinds of wood or lignocellulosic materials with or without additives, water-, acid- or alkaline-solution leaching, etc. on the cement hydration behavior and cement-bonded particleboard (CBPB) properties. According to Eusebio (2004), bagasse particles passed through a $2 \mathrm{~mm}$-sized mesh with the bagasse-cement ratio of 1:2 that should be selected to make $\mathrm{CBPB}$ with the density of $1.00 \mathrm{~g} / \mathrm{cm}^{3}$. Bilba et al. (2003) treated bagasse particles thermally at the temperature of 200 ${ }^{\circ} \mathrm{C}$ to improve the bagasse-cement complex and showed the hydration behavior of the cement. Sedan et al. (2008), Arsene et al. (2007) and Troedec et al. (2011) showed that the alkaline and pyrolysis pre-treatments of the fiber can enhance the flexural strength of the composites, while the acid treatment decreases the properties of the panels. Further improvement of the porosity, durability and strength of the panels can be achieved by adding pozzolanic materials such as fly ash, slag, silica fume and metakaolin (Filho et al., 2003; Juarez et al., 2007). Juarez et al. (2007) treated the fibers with paraffin and added fly ash as a pozzolan admixture to the composite matrix. The performance of the composite was acceptable; so the paraffin treatment reduced the water absorption of the fibers, while the tensile strength was at the sufficient level (Coatanlem et al., 2006). Coatanlem et al. (2006) showed that CBPB properties are improved by saturating the wood particles with sodium silicate due to the formation of ettringite needles enhancing the bonds between wood particles and cement paste.

The diversity of the phenomena potentially occurring in the cement-wood particleboard reinforced by NS is such that linking the $I B$ to its physical origin is hardly achievable. For instance, changes in $I B$ can be induced by different stress concentrations due to the volume and shape of macropores, difference of the effective w/c ratio owing to the absorption of water by wood particles, change of hydration degree of the cement paste, consumption of Portlandite by pozzolanic reactions strengthening the interface between the paste and the wood particles or leakage of soluble organic matters poisoning the hydration of the cement. Hence, it seems that there are many effective factors related to the physical and mechanical properties of CBPB, so that it is necessary to optimize panel production by changing the main effective variables to reduce the negative effect of the poisoning compounds, increasing the performance of the panels in different applications and decreasing the production cost of the panels.

On one hand, common statistical methods involve a great deal of work, and on the other hand, they 
neither predict the properties of the panels nor optimize the production process. However, ANNs have emerged as one of the most useful methods for modeling and optimization in recent years, especially for non-linear problems (Desai et al., 2008). They are especially useful for simulating experimental designs, which are difficult to be explained by physical models. They demonstrate a linkage between input and output data using a series of non-linear functions. The number of layers in the network and the number of neurons in each layer known as architecture are the most important steps in choosing a neural network modeling.

There are a few studies related to the wood-based panel properties based on ANNs such as modeling formaldehyde emission (Akyuz et al., 2017), predicting effect of adding paraffin on physical properties of medium density fiberboard (Gurgen et al., 2019), predicting the internal bond strength of the particleboard under outdoor exposure (Watanabe et al., 2015; Korai and Watanabe, 2016), optimizing the process parameters in wood-based panel production (Cook et al., 2000; Ozsahin, 2013), obtaining the values of the internal bond of the particleboard using the manufacturing parameters (Cook and Chiu, 1997), predicting the particleboard mechanical properties (Fernandez et al., 2008), so on.

Even though there is sufficient literature on the properties of the wood-based panels, only a few systematic investigations are reported so far to correlate the production parameters and properties of CBPBs and predict the panel properties. Hence, in this study, a design is developed from the experimental data that performs experiments to explore the correlation between the production variables including Nano $\mathrm{SiO}_{2}$ content, particle size and weight ratio of bagasse to reed particles and multi-layer perceptron (MLP) model to predict the panel properties.

\section{MATERIALS AND METHODS}

\section{MATERIJALI I METODE}

\subsection{Microstructural investigations}

2.1. Istraživanje mikrostrukture

Reed stalks were collected from a suburb near Zabol City in Sistan-and-Baloochestan Province of Iran. Bagasse particles were obtained from Pars Paper Co. Ltd., Haft Tapeh, Iran. Reed stalks and bagasse particles were milled into fine particles using a hammer mill, and then, the oversized particles were eliminated by an analytical sieve shaker using a sieve with the mesh size of 40 . The commercial grade Portland cement (Type II) was purchased from Sistan Cement Industry Co., Ltd., Iran, to be used as a binder for making cubic samples with the dimensions of $2 \mathrm{~cm} \times 2 \mathrm{~cm} \times 3$ $\mathrm{cm}$. Nano-SiO, powder was purchased from Plasma Chem. GmbH, Berlin, Germany, under the trade name AEROSIL $\AA 200$ to be used as an accelerator additive, and its average BET surface area was $(200 \pm 25) \mathrm{m}^{2} / \mathrm{g}$, with the average particle size of 7-14 nm and the purity $99.80 \%$. In order to disperse Nano in cement well, the Nano was added to the distilled water and ultrasoni- cated (frequency: $20 \mathrm{kHz}$; generating power: $600 \mathrm{~W}$ ) for $6 \mathrm{~min}$ to form nanoparticle suspensions. The prepared suspensions were then used as "mixing water" for preparing cement pastes. The nano- $\mathrm{SiO}_{2}$ powder was used as a replacement of the cement at the weight percentage of $6 \%$ (by dry weight of the cement).

The cement complex was divided into four different mixtures, i.e. the pure cement paste, cement mixed with Nanosilica, cement + Nanosilica mixed with reed fine particles and cement-Nanosilica mixed with bagasse fine particles. Due to the high absorption of the reed and bagasse particles, the cement paste samples were prepared with a high water to cement ratio of 50:50.

After curing the samples for 15 days, scanning electron microscopy (SEM) was employed to study the microstructural changes in the samples with or without Nanosilica. Samples were metallized by a 1-2 nm thick conductive layer of $\mathrm{Au}$ under a vacuum medium after being mounted in the standard form. The morphology was observed by AIS 2100, Seron Technology, Korea. The transmission Fourier-Transform Infrared Spectroscopy (FTIR) technique was used to measure the infrared active cured-cement samples. For this purpose, $1 \mathrm{mg}$ of the powdered samples was blended with $99 \mathrm{mg} \mathrm{KBr}$ as an infrared transparent soft salt in order to obtain the same concentration and avoid variations of the transmittance between the samples. The mixtures were then pressed into a solid disc and then scanned between $400 \mathrm{~cm}^{-1}$ and $4000 \mathrm{~cm}^{-1}$, with a total of 20 scans and a resolution of $8 \mathrm{~cm}^{-1}$ to identify their specific functional groups by a Bruker Optics TENSOR 27 FTIR spectrometer. To consider the crystallinity of the samples, their X-ray diffraction (XRD) patterns were recorded by an Equinox 3000 (INEL, France) wide angle X-ray diffractometer using a $\mathrm{CuK} \alpha$ radiation source with the wavelength of $\lambda=0.154 \mathrm{~nm}$.

\subsection{Board preparation}

2.2. Priprema ploče

The raw materials used in this study were bagasse (sugar cane) and reed (Arondodonax) particles prepared using a disc mill (DM 200, produced by Retsch Co., Germany) and screened by an analytical sieve shaker using sieves to obtain five particle sizes: (1) very large, S1 (10 mm pass/8 mm on); (2) large, S2 ( $8 \mathrm{~mm}$ pass $/ 6 \mathrm{~mm}$ on); (3) medium $\mathrm{S} 3$ (6 mm pass $/ 4$ $\mathrm{mm}$ on); (4) small S4 (4 mm pass/2 $\mathrm{mm}$ on), and very small S5 ( $2 \mathrm{~mm}$ pass). The particles were further oven dried to $5 \%$ moisture content $(M C)$. A commercial grade Portland cement, type II, was used as a bonding agent. The cement ratio of the lignocellulosic particles applied in this study was 1:3 based on the oven dry weight. Calcium chloride $\left(\mathrm{CaCl}_{2}-5 \%\right.$ based on the weight of the cement) was added to the cement complex as the accelerator of the cement hydration. The nominal board density of $1150 \mathrm{~kg} / \mathrm{m}^{3}$ was selected with the weight ratio of bagasse/reed particles at five levels of 2.55:97.45, 6.94:93.06, 13.38:86.62, 19.81:80.19 and 24.20:75.80. In order to produce CBPB, the particles were wetted by water containing $\mathrm{CaCl}_{2}$ and then 
mixed with cement containing $\mathrm{Nano}_{\mathrm{SiO}}$ at five levels (the cement weight $0.48,1.5,3,4.5$ and $5.52 \%$ ) as the third variable of the study. After stirring them for 15 minutes, one-layered mats were formed among two steel plates with the dimensions of $350 \mathrm{~mm} \times 350 \mathrm{~mm}$.

The complex was pressed under a hydraulic press with the thickness of $12 \mathrm{~mm}$ and kept under constant pressure for $24 \mathrm{~h}$ using a press clamp. When the panels were removed from the press, in order to minimize the cement capillary desiccation and improve the hydration process, panels were sprayed by distilled water $(25$ $\mathrm{ml}$ for every panel) and wrapped in a plastic bag before being stored to be cured at $60{ }^{\circ} \mathrm{C}$ for $4 \mathrm{~h}$. Then, bagwrapped samples were conditioned for 28 days at $(25 \pm 2){ }^{\circ} \mathrm{C}$ with $(60 \pm 10) \% \mathrm{RH}$. According to the experimental design and levels of variables, 20 panels were manufactured. After being manufactured, the panels were trimmed and tested for the internal bonding $(I B)$ according to EN 319 (1999). The bonding strength test was performed using a HONSFILD material testing device.

The variance analysis was used to determine the effect of the production parameters on the $I B$ of the panels. For this purpose, the response surface methodology (RSM) was applied.

\subsection{Artificial neural network analysis}

2.3. Analiza uz pomoć umjetne neuronske mreže

The MATLAB Neural Network Toolbox was used to predict the internal bonding strength values of CBPB in response to other levels of the selected variables that were not obtained from the experimental study. In the ANN modeling of the present work, silica content, particle size and bagasse/reed particles ratio were considered as the prime processing variables. Hence, our aim was to reveal the optimum level of each selected variable for each CBPB to obtain the highest internal bonding strength values. The data were obtained from the experimental study.
The performances of the ANN model are evaluated by computing mean-square errors (MSE), rootmean-square errors ( $R M S E)$, mean absolute percentage error $(M A P E)$ and the coefficient of determination $\left(R^{2}\right)$ (Zhang et al., 1998).

In order to minimize $M S E$ and determine the weight and bias values, ANNs training process was followed with MATLAB software package.

Since the error between the actual and predicted outputs must be minimized, the trial and error method was selected to design the back propagation ANN model among several different ANN structures (Zhang et al., 1998), and the parameters including the number of inputs, hidden and output layers and neurons in each layer, transfer functions, number of learning cycles, initialization of the weights and the biases, etc. Levenberg - Marquardt algorithm (trainlm) was used as the training algorithm. However, avoiding overfitting is another important point when applying ANN models. A method for improving generalization is called early stopping, which is provided for all of the supervised network creation functions in Neural Network Toolbox. Therefore, to determine the effects of the particle size, bagasse/reed particles ratio and nanosilica content on the internal bonding strength, and simultaneously to use early stopping method in order to avoid overfitting, the experimental data were divided into three groups: training (for adjusting the weights of the network), validation (for preventing the network in local minima) and testing. Among these data, fourteen samples ( $70 \%$ of the data) were selected for ANN training process, three samples being selected ( $15 \%$ of the data) for the validation set, and the remaining three samples (15\% of the data) for the testing set. The data sets used in the training, test and prediction model are illustrated in Tables 1 and 2 .

A typical multi-layered ANN architecture and the optimum architecture of the ANN model are schematically shown in Figures. 1a and b in terms of the parameters mentioned above. To determine the number of the

Table 1 Training data set and $I B$ prediction model results

Tablica 1. Eksperimentalni podatci i rezultati modela predviđanja čvrstoće na raslojavanje

\begin{tabular}{|c|c|c|c|c|c|}
\hline \multirow{2}{*}{$\begin{array}{l}\text { Nano content } \\
\text { Sadržaj } \\
\text { nanočestica }\end{array}$} & \multirow{2}{*}{$\begin{array}{l}\text { Particle size } \\
\text { Veličina } \\
\text { čestica }\end{array}$} & \multirow{2}{*}{$\begin{array}{l}\text { Weight ratio (bagasse/reed) } \\
\text { Maseni udio } \\
\text { (ostatci od prerade šećerne trske / trska) }\end{array}$} & \multicolumn{3}{|c|}{$\begin{array}{l}\text { Internal bonding, MPa } \\
\text { Čvrstoća na raslojavanje, MPa }\end{array}$} \\
\hline & & & $\begin{array}{l}\text { Measured } \\
\text { Izmjerena }\end{array}$ & $\begin{array}{l}\text { Predicted } \\
\text { Predvidena }\end{array}$ & $\begin{array}{c}\text { Error, \% } \\
\text { Pogreška, \% }\end{array}$ \\
\hline 1.5 & $2-4$ & 19.81:80.19 & 0.42 & 0.4489 & -0.0289 \\
\hline 1.5 & $6-8$ & 6.94:93.06 & 0.18 & 0.1932 & -0.0132 \\
\hline 1.5 & $6-8$ & 19.81:80.19 & 0.32 & 0.3170 & 0.0070 \\
\hline 3 & $<2$ & $13.38: 86.62$ & 0.26 & 0.2508 & 0.0091 \\
\hline 3 & $4-6$ & $2.55: 97.45$ & 0.32 & 0.3915 & -0.0715 \\
\hline 3 & $4-6$ & 13.38:86.62 & 0.47 & 0.4995 & -0.0295 \\
\hline 3 & $4-6$ & $13.38: 86.62$ & 0.48 & 0.4995 & -0.0195 \\
\hline 3 & $4-6$ & 13.38:86.62 & 0.49 & 0.4995 & -0.0095 \\
\hline 3 & $4-6$ & 13.38:86.62 & 0.495 & 0.4995 & -0.0045 \\
\hline 3 & $4-6$ & $13.38: 86.62$ & 0.50 & 0.4995 & -0.0005 \\
\hline 3 & $4-6$ & $24.20: 75.80$ & 0.65 & 0.6370 & 0.0130 \\
\hline 4.5 & $2-4$ & 6.94:93.06 & 0.25 & 0.2424 & 0.0075 \\
\hline 4.5 & $6-8$ & $6.94: 93.06$ & 0.22 & 0.2413 & -0.0213 \\
\hline 5.52 & $4-6$ & 13.38:86.62 & 0.33 & 0.3608 & -0.0309 \\
\hline
\end{tabular}


Table 2 (A) Testing data set and (B) validation data set of $I B$ prediction model results

Tablica 2. (A) Skup izmjerenih podataka i (B) skup podataka za provjeru valjanosti rezultata modela predviđanja čvrstoće na raslojavanje

\begin{tabular}{|c|c|c|c|c|c|}
\hline \multirow{2}{*}{$\begin{array}{c}\text { Nano } \\
\text { content } \\
\text { Sadržaj } \\
\text { nanočestica }\end{array}$} & \multirow{2}{*}{$\begin{array}{c}\text { Particle size } \\
\text { Veličina čestica }\end{array}$} & \multirow{2}{*}{$\begin{array}{l}\text { Weight ratio (bagasse/reed) } \\
\text { Maseni udio (ostatci od prerade } \\
\text { šé́erne trske / trska) }\end{array}$} & \multicolumn{3}{|c|}{$\begin{array}{c}\text { Internal bonding, } \mathbf{M P a} \\
\text { Čvrstoća na raslojavanje, } \mathrm{MPa}\end{array}$} \\
\hline & & & $\begin{array}{l}\text { Measured } \\
\text { Izmjerena }\end{array}$ & $\begin{array}{l}\text { Predicted } \\
\text { Predviđena }\end{array}$ & $\begin{array}{c}\text { Error, \% } \\
\text { Pogreška, \% }\end{array}$ \\
\hline \multicolumn{6}{|c|}{$\begin{array}{l}\text { (A): Testing data set and } I B \text { prediction model results } \\
\text { (A): Skup izmjerenih podataka i rezultati modela predviđanja čvrstoće } \\
\text { na raslojavanje }\end{array}$} \\
\hline 0.45 & $4-6$ & $13.38: 86.62$ & 0.21 & 0.2245 & -0.0145 \\
\hline 1.5 & $2-4$ & 6.94:93.06 & 0.20 & 0.2311 & -0.0311 \\
\hline 3 & $4-6$ & 13.38:86.62 & 0.493 & 0.4995 & -0.0065 \\
\hline \multicolumn{6}{|c|}{$\begin{array}{l}\text { (B): Validation data set and } I B \text { prediction model results } \\
\text { (B): Skup podataka za provjeru valjanosti i rezultati modela predviđanja } \\
\text { črstoće na raslojavanje }\end{array}$} \\
\hline 4.5 & 8 & $19.81: 80.19$ & 0.43 & 0.4335 & -0.0035 \\
\hline 3 & 9.36 & $13.38: 86.62$ & 0.19 & 0.1955 & -0.0055 \\
\hline 4.5 & 4 & 19.81:80.19 & 0.52 & 0.5045 & +0.0155 \\
\hline
\end{tabular}

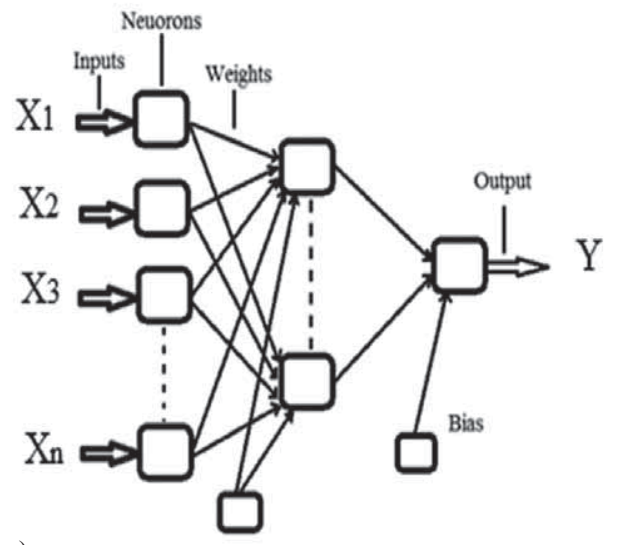

a)

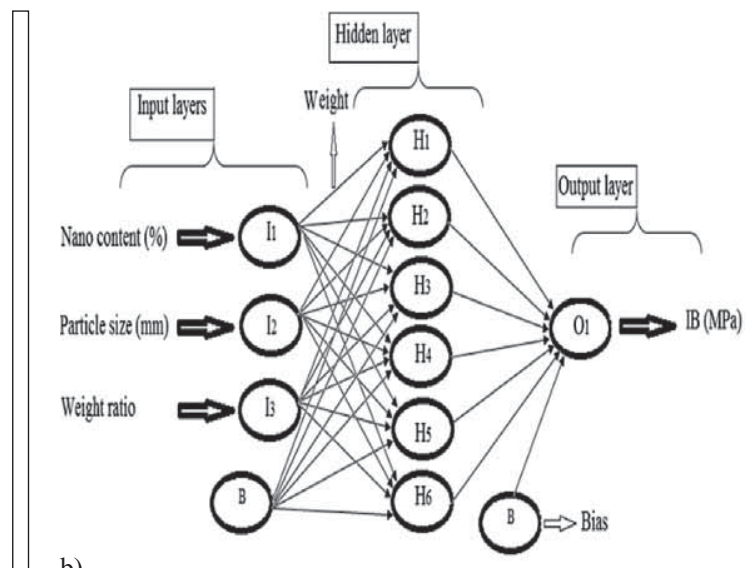

b)

Figure 1 (a) A typical multi-layered ANN architecture and (b) ANN architecture used as prediction model for $I B$ Slika 1. (a) Tipična višeslojna ANN arhitektura i (b) ANN arhitektura upotrijebljena kao model predviđanja čvrstoće na raslojavanje

hidden layer neurons, 6 neurons were finally considered in this layer after following the method of trial and error and repetition in the training of the network by changing the number of neurons from 0 to 20 in the hidden layer. In this condition, the network showed the best performance, so that as the number of neurons decreased or increased in the hidden layer, the efficiency of the network decreased and the network did not learn.

Before training the network, the data sets were normalized using their minimum and maximum values within the range of -1 to 1 by applying the hyperbolic tangent sigmoid function in order to prevent any calculation error related to different parameter magnitudes. The normalized data were finally converted into the original scale using a reverse normalizing process to evaluate the results with MATLAB software. The ANN's training process was discontinued after 3 epochs because of the mean square error of 0.000658 . Figure 2 estimates the error along with iterative process to determine the best network architecture.

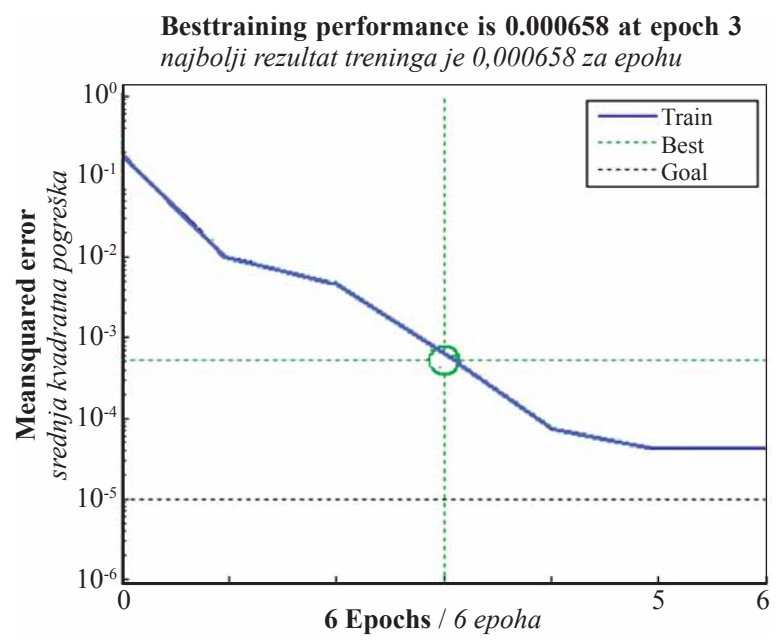

Figure 2 Evolution of error during iterative process for ANN

Slika 2. Evolucija pogreške tijekom iterativnog postupka za ANN 


\section{RESULTS AND DISCUSSION}

\section{REZULTATI I RASPRAVA}

\subsection{Microstructural study}

\subsection{Istraživanje mikrostrukture}

SEM examinations were performed to study the morphology and microstructure of the pure cement sample, samples with nanosilica, samples with nanosilica and bagasse fine particles and samples with nanosilica and reed fine particles for 15 days. In Figure $3 \mathrm{~A}$ (pure sample), a large amount of $\mathrm{Ca}(\mathrm{OH})_{2}(\mathrm{CH})$ crystals and a high level of porosity can be observed in the composite mass of the calcium silicate hydrate (C$\mathrm{S}-\mathrm{H})$ with a foil-like or platy shape and monosulphate, showing that without nanosilica, large air pores with many plate-like hydrates are formed in the hardened cement, and that $\mathrm{Ca}(\mathrm{OH})_{2}$ has enough space to grow.

Due to the availability of the void space for uninhibited growth situations, as NS is added to the cement paste, $\mathrm{CH}$ formation changes and dense and compact structures of other hydration products are produced such as $\mathrm{C}-\mathrm{S}-\mathrm{H}$ and monosulphate, while $\mathrm{Ca}(\mathrm{OH})_{2}$ crystals are reduced (Figure $3 \mathrm{~B}$ ). In fact, nano- $\mathrm{SiO}_{2}$ additives can fill the pores in the cement by activating pozzolanic reaction, reacting with $\mathrm{CH}$ in the solution to produce more C-S-H, so that the micro-structure of the samples with nano- $\mathrm{SiO}_{2}$ is denser than that of the samples without nano- $\mathrm{SiO}_{2}$. In fact, most of the ettringite and C-S-H crystals were covered by the added NS and this addition accelerated the hydration process. This created more compaction, so that the hydration products were produced fully, they filled the pores and $\mathrm{Ca}(\mathrm{OH})_{2}$ was not observed. This improved the mechanical properties of the cement complex.

SEM images provide evidence of a denser structure of hydrated products in the cement paste containing NS, and the occurrence of micro- or/and nano-cracks in the cement paste reinforced by reed is likely due to a lower effective water to cement ratio as a part of water has been absorbed by reed. (Figures 3C and 3D).

As the addition of organic and hydrophilic lignocellulosic-based materials greatly increases the viscosity of the cementitious mixtures (Spiesz and Brouwers, 2014; Rupasinghe et al., 2017), the increase in the porosity of hardened cement at microscale is expected due to the formation of a large amount of air cavities entrapped in the cementitious system. Since the organic materials are not saturated, they absorb some water from the cement paste, thus reducing its effective water-to-cement ratio and increasing its viscosity.

On the other hand, evaluation of the hydration process of the cement paste mixed with accelerators can show the changes in the properties of not only cement paste but also cement-binder-based panels. According to Xie et al. (2016), the intensity of the changes in the hydration behavior of lingo-cement systems is related to differences in the existing amount of poisonous component in the lignocellulosic materials such as sugars, which delay the hydration process. In order to accelerate the hydration process and according to the first step of this study (Nazerian et al., 2018), it was determined that the addition of pozzolanic materials such as $\mathrm{SiO}_{2}$ can accelerate the hydration process, so that adding $3 \%$ nano $\mathrm{SiO}_{2}$ (based on cement weight) to the cement paste even containing bagasse or reed fine particle raised the maximum hydration temperature, while the time of reaching the main rate peak shortened. Also, the increase of $\mathrm{SiO}_{2}$ replacement shortened the setting time.

Besides, due to the nucleation effect of nanosilica in the system and the corresponding increase in the cement hydration and C-S-H generation, the formation of air voids can be limited using an optimal nanosilica content. Since the water defining the water/cement ratio includes the water required to saturate the dry reed particles, the effective water to cement ratio is likely decreased by adding reed particles. It might be decreased to the point that the hydration of the cement becomes incomplete. With respect to the fact that one of the most important cement hydration products is C$\mathrm{S}-\mathrm{H}$ as a product of this pozzolanic reaction, which is made by mixing calcium hydroxide $(\mathrm{CH})$ and silica in the presence of water due to the lake of sufficient water, $\mathrm{CH}$ production decreases in the hydration process, so that less C-S-H is formed.

Since the structure of cement systems is very sensitive to the moisture movement during the hydration (due to the existence of hydrophilic fiber elements), the lower effective $\mathrm{w} / \mathrm{c}$ ratio may also explain the occurrence of microcracks induced by shrinkage (Jennings et al., 2007) that are visible on SEM images, as shown in Figure 3C. The positive influence of NS addition is due to the filling ability and the Pozzolanic activity, which results in C-S-H formation (Raiess Ghasemi et al., 2010). Hence, it seems that the addition of nano $\mathrm{SiO}_{2}$ can compensate for the negative effect of using reed particles in the cementitious systems.

The addition of nanosilica formed a dense and uniform structure in the hardened cement by increasing the C-S-H gel content. However, a stronger water absorption ability in the spongy structure of bagasse compared to denser reed particles leads to a higher decrease in the system water, which makes the cement grains unhydrated (Figure 3D). Hence, cement hydration and generation of $\mathrm{CH}$ are delayed or limited. As $\mathrm{CH}$ decreases, the formation of C-S-H gel dense structure is limited as a result of the reaction of NS with $\mathrm{CH}$, and hence, the porosity of the hardened cement is relatively large.

Figure 4 shows the FTIR spectra of the pure cement paste $(\mathrm{CP})$, cement-nanosilica $(\mathrm{CN})$ mixture and cement paste reinforced by reed (CNR) and bagasse (CNB) fibers with nanosilica after being cured for 15 days. The broad absorption bands of IR spectra are observed in the range of $3800-3000 \mathrm{~cm}^{-1}$, corresponding to the stretching vibrations of both structural and free $-\mathrm{OH}$ groups of water, $\mathrm{CH}$ and $\mathrm{CSH}$ gel with maxima close to $3446 \mathrm{~cm}^{-1}$ (Xu et al., 1999; Kontoleontos et al., 2012 ,). The intensity of the band at $3446 \mathrm{~cm}^{-1}$ for $\mathrm{CP}$, $\mathrm{CN}$ and $\mathrm{CNB}$ was similar, while that of CNR decreased a little compared to others. In addition, the IR spectra of this band shifted slightly to $3420 \mathrm{~cm}^{-1}$ and became broader and smaller. According to $\mathrm{Xu}$ et al. (1999), 
....... Nazerian, Nanaii, Vatankhah, Koosha: Performance of ANN in Predicting Internal...
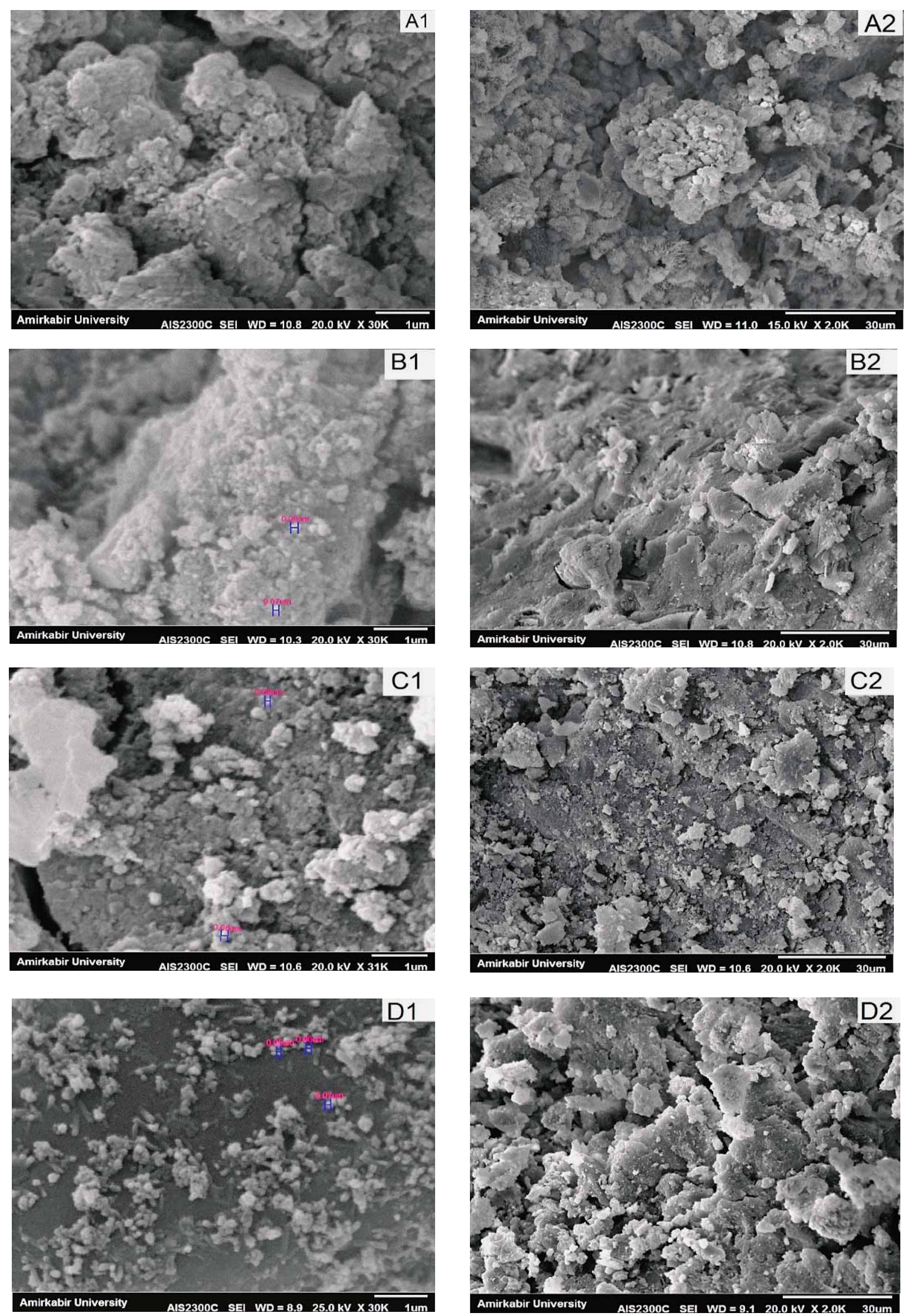

Figure 3 SEM micrographs: (A) pure hardened cement paste, (B) $6 \%$ nanosilica-cement paste, (C) $6 \%$ nanosilica-cement paste-reed fiber, and (D) $6 \%$ nanosilica-cement paste-bagasse fiber, after 15 days of curing

Slika 3. SEM mikrografije: (A) čista otvrdnuta cementna pasta, (B) $6 \%$-tna nanosilikatno-cementna pasta, (C) $6 \%$-tna nanosilikatno-cementna pasta - vlakna trske i (D) $6 \%$-tna nanosilikatno-cementna pasta - vlakna ostataka od prerade šećerne trske 15 dana nakon otvrdnjivanja 


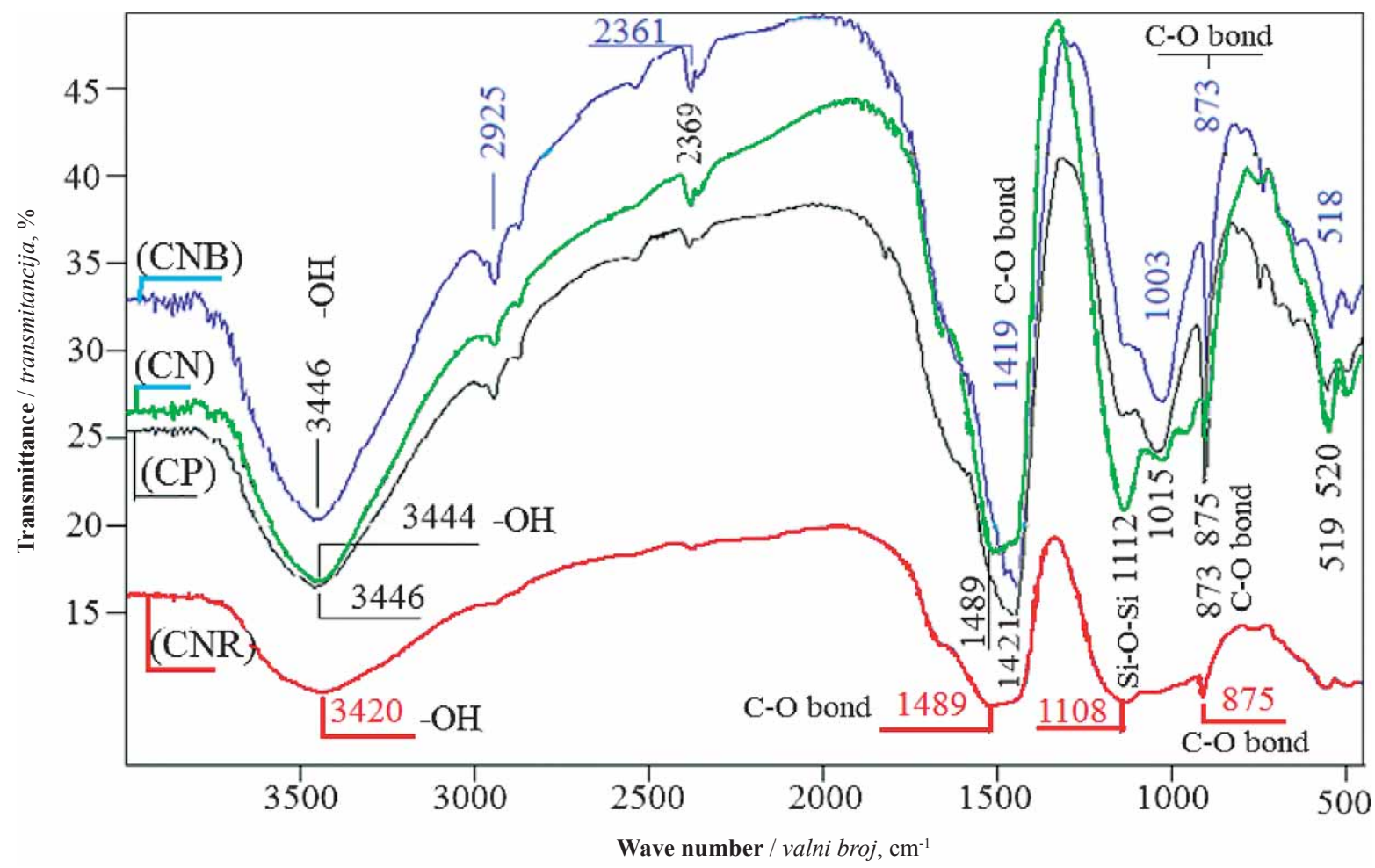

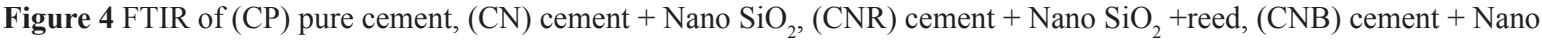
$\mathrm{SiO}_{2}+$ bagasse

Slika 4. FTIR (CP) čistog cementa, $(\mathrm{CN})$ cementa + nano $\mathrm{SiO}_{2},(\mathrm{CNR})$ cementa + nano $\mathrm{SiO}_{2}+$ trska, $(\mathrm{CNB})$ cementa + nano $\mathrm{SiO}_{2}+$ ostatak od prerade šećerne trske

Bjornstrom et al. (2004) and Kontoleontos et al. (2012) a decrease in the amount of bonded-OH groups and free water or the equivalent reduction in $\mathrm{Ca}(\mathrm{OH})_{2}$ content and an increase in $\mathrm{C}-\mathrm{S}-\mathrm{H}$ content in $\mathrm{CNR}$ are the reasons of the changes in IR spectra.

According to the spectra, the gelation mechanism and siloxane bond ( $\mathrm{Si}-\mathrm{O}-\mathrm{Si}$ ) formation, due to the absorption band with the wave number of $1112 \mathrm{~cm}^{-1}$, occurred in the samples containing nanosilica $(\mathrm{CN})$, which is more than that in the $\mathrm{CP}$ (the presence of valley in the curve (CP)). This can be related to the fact that the reduction of the repulsion effect of $\mathrm{Ca}^{2+}$ and $\mathrm{Al}^{3+}$ formed from cement dissolution as a gelling agent on the nanosilica inter-particles net accelerates the gelation process (Innocentini et al., 2002), in which hydroxyl groups $(\mathrm{Si}-\mathrm{OH})$ on the surface of silica are converted into siloxane bonds, and a three-dimensional network is formed (Anjos et al., 2008), affecting the strength of the hardened cement.

According to the FTIR spectrum of $\mathrm{CP}$ and CNB systems, two distinct peaks are observed around 1420 $\mathrm{cm}^{-1}$ and $873 \mathrm{~cm}^{-1}$ related to the stretching and bendingin-plane vibrations of the $\mathrm{C}-\mathrm{O}$ bonds of $\mathrm{CH}$ and $\mathrm{CaCO}_{3}$, resulting from the reaction between $\mathrm{Ca}(\mathrm{OH})_{2}$ and $\mathrm{CO}_{2}$ in the air (Y1lmaz and Olgun, 2008; Chang and Chen, 2006; Fernandez-Carrasco and Vazquez, 2009). The intensity of the band at $1420 \mathrm{~cm}^{-1}$ is assumed to be closely related to the ratio and depth of the carbonation (Chang and Chen, 2006; Fernandez-Carrasco and Vazquez, 2009). The bands at $1420 \mathrm{~cm}^{-1}$ and $873 \mathrm{~cm}^{-1}$ shifted slightly to $1489 \mathrm{~cm}^{-1}$ and $875 \mathrm{~cm}^{-1}$ in the FTIR spectra of $\mathrm{CN}$ and CNR samples after being cured for 15 days, re- spectively. The intensities of the bands at $1489 \mathrm{~cm}^{-1}$ and $1420 \mathrm{~cm}^{-1}$ of CNR were smaller than those of CNB, CN and $\mathrm{CP}$, indicating the decrease in the carbonation ratio and depth in these samples. Similarly, the bending-inplane vibrations of the $\mathrm{C}-\mathrm{O}$ bonds at $873 \mathrm{~cm}^{-1}$ (Chang and Chen, 2006) had lower intensities in the IR spectra of the CNR sample. According to these bands, carbonation increases as NS is added. In addition, CP paste exhibits a higher rate of carbonation than other cement complexes. The small $\mathrm{OH}$ bands from $\mathrm{Ca}(\mathrm{OH})_{2}$ of the samples containing nanosilica may be due to their reaction with $\mathrm{SiO}_{2}$-based $\mathrm{CSH}$. This means that nanosilica enhances the crystallinity of portlandite and increases the density of the structure of the cement complex at microscale and improves the mechanical properties of the hardened cement.

Figure 5 shows the XRD analysis of the hydration behavior of the hardened cementitious samples in four compositions: pure cement (A), cement with nanosilica (B), cement with nanosilica and reed fine particles (C) and cement with nanosilica and bagasse fine particles (D). Comparing XRD spectra of (A), (B), (C) and (D) compositions, the peaks of calcium hydroxide $\left(\mathrm{Ca}(\mathrm{OH})_{2}\right)$ at $17.8^{\circ}, 28.5^{\circ}, 34^{\circ}, 50.5^{\circ}, 54^{\circ}$ and $62.7^{\circ}(2 \theta)$ (Singh et al., 2016; Nakanishi et al., 2016) appear in the XRD spectrum of (A), they become more intense in the samples (B) and (C), while they disappear or weaken in the cement pastes containing nanosilica with bagasse. In fact, the intensity of these peaks is largest for portlandite in the cement with nanosilica, reducing gradually as reed and bagasse particles are applied. Due to the high performance of $\mathrm{SiO}_{2}$ to form pozzo- 


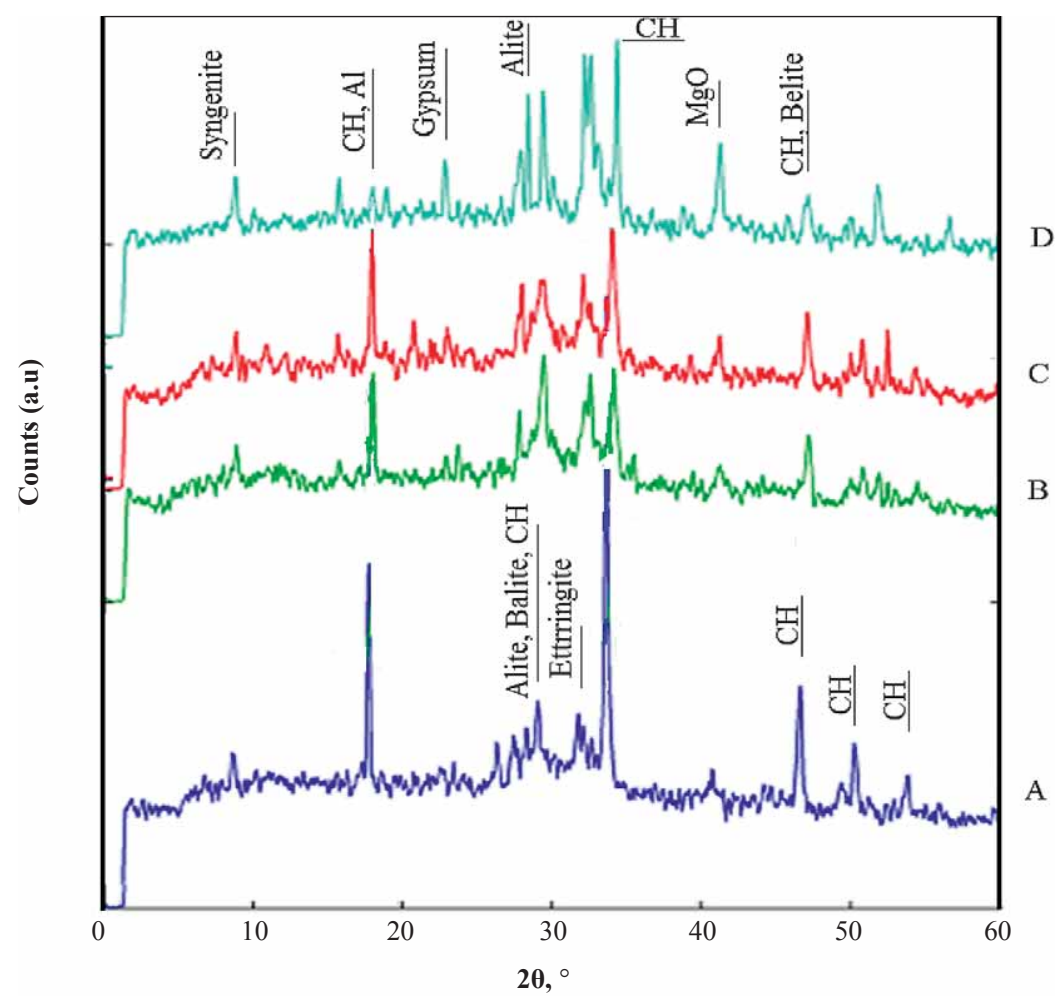

Figure 5 XRD analysis of (A) pure cement, (B) cement + Nano $\mathrm{SiO}_{2}$, (C) cement + Nano $\mathrm{SiO}_{2}+$ reed, (D) cement $+\mathrm{Nano}$ $\mathrm{SiO}_{2}+$ bagasse

Slika 5. XRD analiza (A) čistog cementa, (B) cementa + nano $\mathrm{SiO}_{2}$, (C) cementa + nano $\mathrm{SiO}_{2}+$ trska, (D) cementa + nano $\mathrm{SiO}_{2}+$ ostatak od prerade šećerne trske

lanic reactions with $\mathrm{CH}$, the intensity of these peaks is observed in the samples (C) and (D) and increases largely in the sample (B).

Apparently, these spectroscopic results foresee the weaker strength of CBPB made with bagasse particles resulting from insufficient formation of hydrate products at the bagasse particles interface. On the other hand, compared to pure cement pastes (A), the decrease in the calcium hydroxide XRD peaks in the cement pastes containing nanosilica illustrates that $\mathrm{CH}$ can react with $\mathrm{SiO}_{2}$ and form more $\mathrm{CSH}$ gel as it was mentioned in previous studies (Rupasinghe et al., 2017; Lavergne et al., 2019).

A peak near $42.9^{\circ}(2 \theta)$ can be related to periclase $\mathrm{MgO}$ (Stutzman et al., 2016), which may slowly react with water and trigger an expansion of the concrete, though the porosity and local low relative humidity likely prevent such a phenomenon. Furthermore, Portlandite features a peak near $47^{\circ}(2 \theta)$. These peaks at $47^{\circ}(2 \theta)$ look smaller or wider for mixes containing $\mathrm{CH}$ : it might be due to the smaller amount of $\mathrm{CH}$ or the size of $\mathrm{CH}$ crystal being nearly at nanometric scale. The peak near $34^{\circ}(2 \theta)$ is reduced by NS in a similar manner. These two peaks can disappear as the pozzolanic reaction entirely consumes the $\mathrm{CH}$ (Maddalena et al., 2019).

It is found that the intensity of the peaks is similar around $9^{\circ}(2 \theta)$ for syngenite, while the intensity of the peaks around $18^{\circ}(2 \theta)$ for portlandite, $23^{\circ}(2 \theta)$ for gypsum and $33^{\circ}(2 \theta)$ for aluminate in the pure cement (Stutzman et al., 2016) reaches the minimum, and then increases slightly as nanosilica and bagasse particles are added. Some of these peaks increased as reed parti- cles were added. Due to the increment of the final amount of cement hydration products, the intensity of these peaks disappeared or decreased. It can be attributed to the fact that nanosilica can improve the hydration of cement, enabling the production of more hydration products such as ettringite. Ettringite needles are formed due to better bonds between reed or bagasse particles and cement paste (Coatanlem et al., 2006).

It is known that $\mathrm{C}_{3} \mathrm{~S}$ (alite) and $\mathrm{C}_{2} \mathrm{~S}$ (belite) are fundamental contributors to the early strength development of the cement paste due to the reaction of $\mathrm{C}_{3} \mathrm{~S}$ and $\mathrm{C}_{2} \mathrm{~S}$ with sufficient water and with $\mathrm{C}-\mathrm{S}-\mathrm{H}$ gel formation acting as a binder. The addition of silica accelerates the formation of C-S-H gel. However, comparing XRD spectra of samples, alite peaks at $27.5^{\circ}(2 \theta)$ and $29.2^{\circ}$

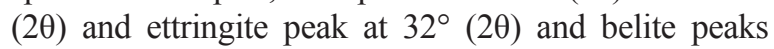
around $29^{\circ}$ and $48^{\circ}(2 \theta)$ (Wei et al., 2003) appear in the spectrum of the cement paste containing $6 \%$ nanosilica with reed and bagasse particles at the maximum intensity, while these peaks decrease in the cement pastes containing only $6 \%$ nanosilica to the minimum intensity in the pure cement as shown in Figure 5.

In fact, in this analysis, XRD peak patterns corresponding to the phases $\mathrm{C}_{2} \mathrm{~S}$ and $\mathrm{C}_{3} \mathrm{~S}$ increase as lignocellulosic particles are used due to the decrease of the hydration process. Due to the high specific surface area and the high ability of nano particles to absorb water molecules on one hand, and the high absorbent characteristics of carbohydrate chains, as well as the existence of a spongy tissue in the inner layer of reed or bagasse cane on the other hand, the amount of water is not sufficient to complete the hydration process and 
form C-S-H gel. Hence, substitution of cement with nanosilica and addition of lignocellulosic particles to the cement paste matrix result in the excessive consumption of water and absorption of a part of the water for hydration. Therefore, this observation agrees with the statement that a threshold of nanosilica content needs to be considered to enhance the hydrated cement paste properties through pozzolanic reactions (Mondal et al., 2010; Kim et al., 2010).

\subsection{Experimental results}

\subsection{Eksperimentalni rezultati}

Apparently, these spectroscopic results foresee the weaker strength of CBPB made with bagasse particles resulting from insufficient formation of hydrate products at the bagasse particles interface. On the other hand, compared to pure cement pastes (A), the decrease in the calcium hydroxide XRD peaks in the cement pastes containing nanosilica illustrates that $\mathrm{CH}$ can react with $\mathrm{SiO}_{2}$ and form more CSH gel, as mentioned in previous studies (Rupasinghe et al., 2017; Lavergne et al., 2019).

A peak near $42.9^{\circ}(2 \theta)$ can be related to periclase $\mathrm{MgO}$ (Stutzman et al., 2016), which may slowly react with water and trigger an expansion of the concrete, though the porosity and local low relative humidity likely prevent such a phenomenon. Furthermore, Portlandite features a peak near $47^{\circ}(2 \theta)$. These peaks at $47^{\circ}(2 \theta)$ look smaller or wider for mixes containing $\mathrm{CH}$ : it might be due to the smaller amount of $\mathrm{CH}$ or the size of $\mathrm{CH}$ crystal being nearly at nanometric scale. The peak near $34^{\circ}(2 \theta)$ is reduced by NS in a similar manner. These two peaks can disappear as the pozzolanic reaction entirely consumes the CH (Maddalena et al., 2019).

It is found that the intensity of the peaks is similar around $9^{\circ}(2 \theta)$ for syngenite, while the intensity of the peaks round $18^{\circ}(2 \theta)$ for portlandite, $23^{\circ}(2 \theta)$ for gypsum and $33^{\circ}(2 \theta)$ for aluminate in the pure cement (Stutzman et al. 2016) reaches the minimum, and then increases slightly as nanosilica and bagasse particles are added. Some of these peaks increased as reed particles were added. Due to the increment of the final amount of cement hydration products, the intensity of these peaks disappeared or decreased. It can be attributed to the fact that nanosilica can improve the hydration of cement enabling the production of more hydration products such as ettringite. Ettringite needles are formed due to better bonds between reed or bagasse particles and cement paste (Coatanlem et al., 2006).
It is known that $\mathrm{C}_{3} \mathrm{~S}$ (alite) and $\mathrm{C}_{2} \mathrm{~S}$ (belite) are fundamental contributors to the early strength development of the cement paste due to the reaction of $\mathrm{C}_{3} \mathrm{~S}$ and $\mathrm{C}_{2} \mathrm{~S}$ with sufficient water and with $\mathrm{C}-\mathrm{S}-\mathrm{H}$ gel formation acting as a binder. The addition of silica accelerates the formation of C-S-H gel. However, comparing XRD spectra of samples, alite peaks at $27.5^{\circ}(2 \theta)$ and $29.2^{\circ}$

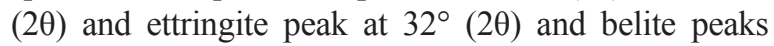
around $29^{\circ}$ and $48^{\circ}(2 \theta)$ (Wei et al., 2003) appear in the spectrum of the cement paste containing $6 \%$ nanosilica with reed and bagasse particles at the maximum intensity, while these peaks decrease in the cement pastes containing only $6 \%$ nanosilica to the minimum intensity in the pure cement as shown in Figure 5.

In fact, in this analysis, XRD peak patterns corresponding to the phases $\mathrm{C}_{2} \mathrm{~S}$ and $\mathrm{C}_{3} \mathrm{~S}$ increase as lignocellulosic particles are used due to the decrease of the hydration process. Due to the high specific surface area and the high ability of nano particles to absorb water molecules on one hand, and the high absorbent characteristics of carbohydrate chains as well as the existence of a spongy tissue in the inner layer of reed or bagasse cane on the other hand, the amount of water is not sufficient to complete the hydration process and form C-S-H gel. Hence, substitution of cement with nanosilica and addition of lignocellulosic particles to the cement paste matrix result in the excessive consumption of water and absorption of a part of the water for hydration. Therefore, this observation agrees with the statement that a threshold of nanosilica content needs to be considered to enhance the hydrated cement paste properties through pozzolanic reactions (Mondal et al., 2010; Kim et al., 2010).

The calculated RMSE, MAPE and $R^{2}$ statistics of the ANN model are listed in Table 4. As seen in Table 4, RMSE, MSE, MAPE and $R^{2}$ were found to be 0.0256 , $0.00066,1.988 \%$ and 0.9727 for the training data, $0.02,0.004,2.894 \%$ and 0.9970 for the validation data, and $0.202,0.0004,1.455 \%$ and 0.9972 for the testing data. One of the most important evaluation criteria is $M A P E$. It is generally used to determine the prediction accuracy as the primary criterion. According to Table 4, MAPE values of the model range from 1.455 $\%$ to $2.894 \%$ for IB. The error values are satisfactory. The results of the MAPE have ascertained that the performance of the model developed for the prediction of $I B$ is quite good.

Another important evaluation criterion is $R^{2}$, which shows the extent of similarity or relationship be-

Table 3 ANOVA results for $I B$ (only significant terms)

Tablica 3. ANOVA rezultati za čvrstoću na raslojavanje (samo značajni rezultati)

\begin{tabular}{|c|c|c|c|c|c|}
\hline Source & $\boldsymbol{S S}$ & $\boldsymbol{D F}$ & $\boldsymbol{M S}$ & $\boldsymbol{F}$ value & Prob $>$ F \\
\hline Model & 0.37 & 7 & 0.053 & 563.25 & $<0.0001$ \\
\hline A & 0.018 & 1 & 0.018 & 197.24 & $<0.0001$ \\
\hline B & $9.370 \mathrm{E}-003$ & 1 & $9.370 \mathrm{E}-003$ & 100.23 & $<0.0001$ \\
\hline C & 0.14 & 1 & 0.14 & 1524.21 & $<0.0001$ \\
\hline $\mathrm{A}^{2}$ & 0.086 & 1 & 0.086 & 919.53 & $<0.0001$ \\
\hline $\mathrm{B}^{2}$ & 0.13 & 1 & 0.13 & 1339.66 & $<0.0001$ \\
\hline AC & $1.800 \mathrm{E}-003$ & 1 & $1.800 \mathrm{E}-003$ & 19.25 & 0.0009 \\
\hline BC & $2.450 \mathrm{E}-003$ & 1 & $2.450 \mathrm{E}-003$ & 26.21 & 0.0003 \\
\hline
\end{tabular}


Table 4 Evaluation results in terms of performance criteria of ANN model

Tablica 4. Rezultati evaluacije kriterija izvedbe ANN modela

\begin{tabular}{|l|c|c|c|c|}
\hline \multirow{2}{*}{$\begin{array}{l}\text { Data sets } \\
\text { Skup podataka }\end{array}$} & \multicolumn{4}{|c|}{ IB, MPa } \\
\cline { 2 - 5 } & $R M S E$ & $M S E$ & $\begin{array}{c}\text { MAPE, } \\
\%\end{array}$ & $R^{2}$ \\
\hline Training / trening & 0.0256 & 0.0006 & 1.988 & 0.9727 \\
\hline $\begin{array}{l}\text { Validation } \\
\text { validacija }\end{array}$ & 0.0200 & 0.0004 & 2.894 & 0.9970 \\
\hline Testing / testiranje & 0.0202 & 0.0004 & 1.455 & 0.9972 \\
\hline
\end{tabular}

tween the actual data and the predicted data. If $R^{2}$ value is less than 0.82 , the relationship is poor, if it is between 0.82 and 0.90 , the relationship is good, and if it is more than 0.91, the relationship is excellent (Shenk and Westerhaus 1996). As shown in Table 4 and Figure $6, R^{2}$ values are greater than 0.91 , which means that the predictive success of the model is good. According to the statistical analyses, RMSE, MSE, MAPE and $R^{2}$ are acceptable for the internal bonding and meet the accuracy of the ANN learning and testing stages (Table 4). As confirmed by the results, the ANN approach has a sufficient validity rate to predict the internal bonding value of the cement-bonded particleboard.

There is limited information on the prediction of the mechanical properties of non-wood based cementbonded composites. However, several studies have been conducted on some strength properties of the wood-based panels. Fernandez et al. (2008) obtained the $R^{2}$ values of 0.75 and 0.76 to predict the MOR and $M O E$ of the particleboard by ANN, respectively. In another study, $R^{2}$ value of the regression model was 0.70 to predict the internal bonding of the particleboard (Cook and Whittaker, 1992). Eslah et al. (2012) found the $\mathrm{R}^{2}$ values of 0.79 and 0.69 to predict the MOR and $M O E$ of the particleboard, respectively, using the regression model. Watanabe et al. (2015) obtained the $R^{2}$ value of 0.93 to predict the internal bonding strength of the particleboard by ANN (15). Ozsahin (2013) determined the $R^{2}$ values as $0.973,0.983$ and 0.853 to predict the moisture absorption, thickness swelling and thermal conductivity of OSB by ANN. Thus, it can be seen that the $R^{2}$ values obtained by ANN models developed in this study are higher compared to those obtained by the above-mentioned modeling applications to predict the cement-based wood composites.

The model outputs of the training, validation and testing data and their comparisons with the actual outputs of the internal bonding strength are given in Figure 7 for each data set.

Also, the comparison of the actual values and the ANN prediction values are illustrated graphically in Figure 8 for all data. The results of the graphical comparisons showed similar internal bonding properties between the experimental study and the outputs obtained by ANN model and guaranteed the validity of the model. The results indicate that there is a permanent agreement between the outputs of the ANN model and the experimental data. This implies that the ANN model can be
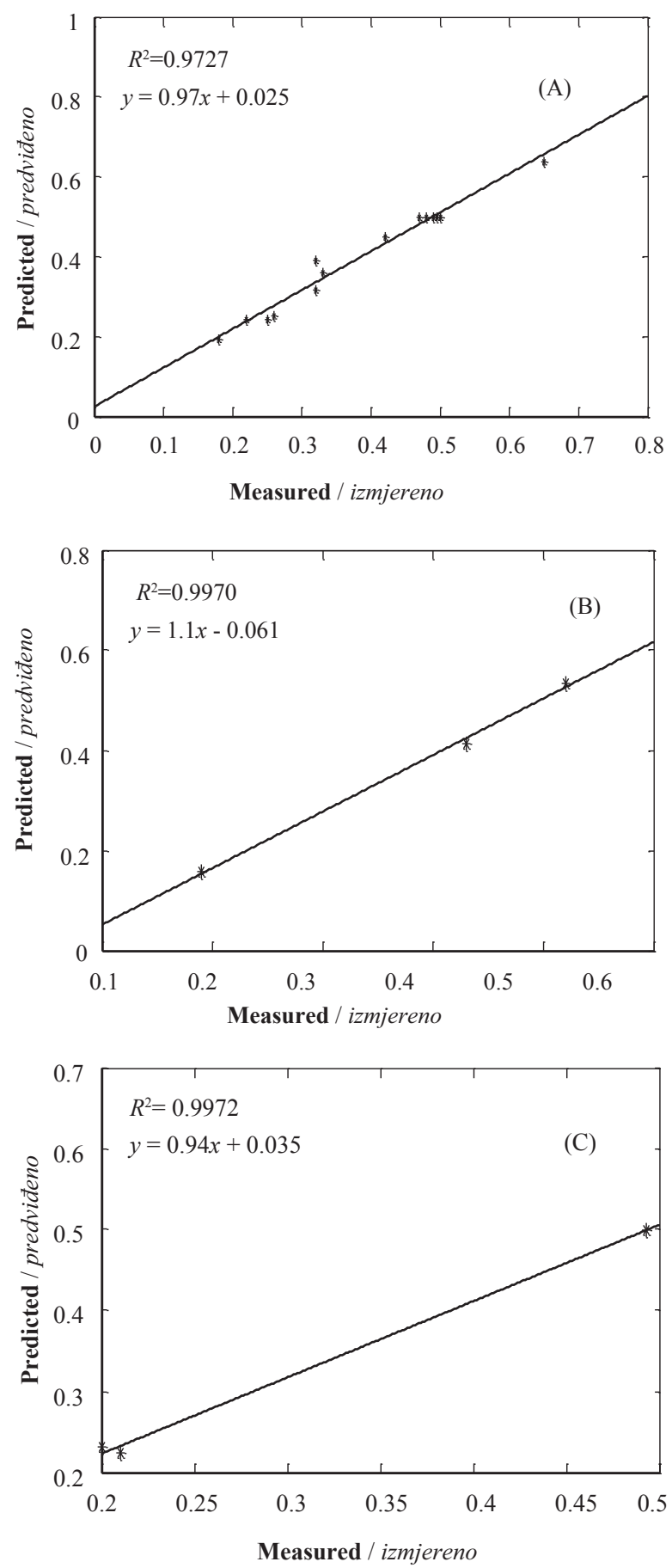

Figure 6 Presentation of fit between actual and predicted values of $I B$ for training (a), validation (b) and testing data (c) Slika 6. Prikaz podudaranja stvarnih i predviđenih vrijednosti $I B-a$ (a) za trening, (b) za validaciju te (c) za ispitne podatke

used to optimize the internal bonding strength value of the panels. Hence, values estimated by ANN model can be used to produce panels rather than the measured data, which reduces the testing time and cost.

Generally, all outputs of the effects of the production factors on the internal bonding strength of the panels can be estimated by the designed model for innumerable combinations. According to Figure 9, the predictive changes in the internal bonding are presented graphically for different nano contents and lignocellulosic particle sizes when bagasse/reed weight ratio is $13.38 \%$. 

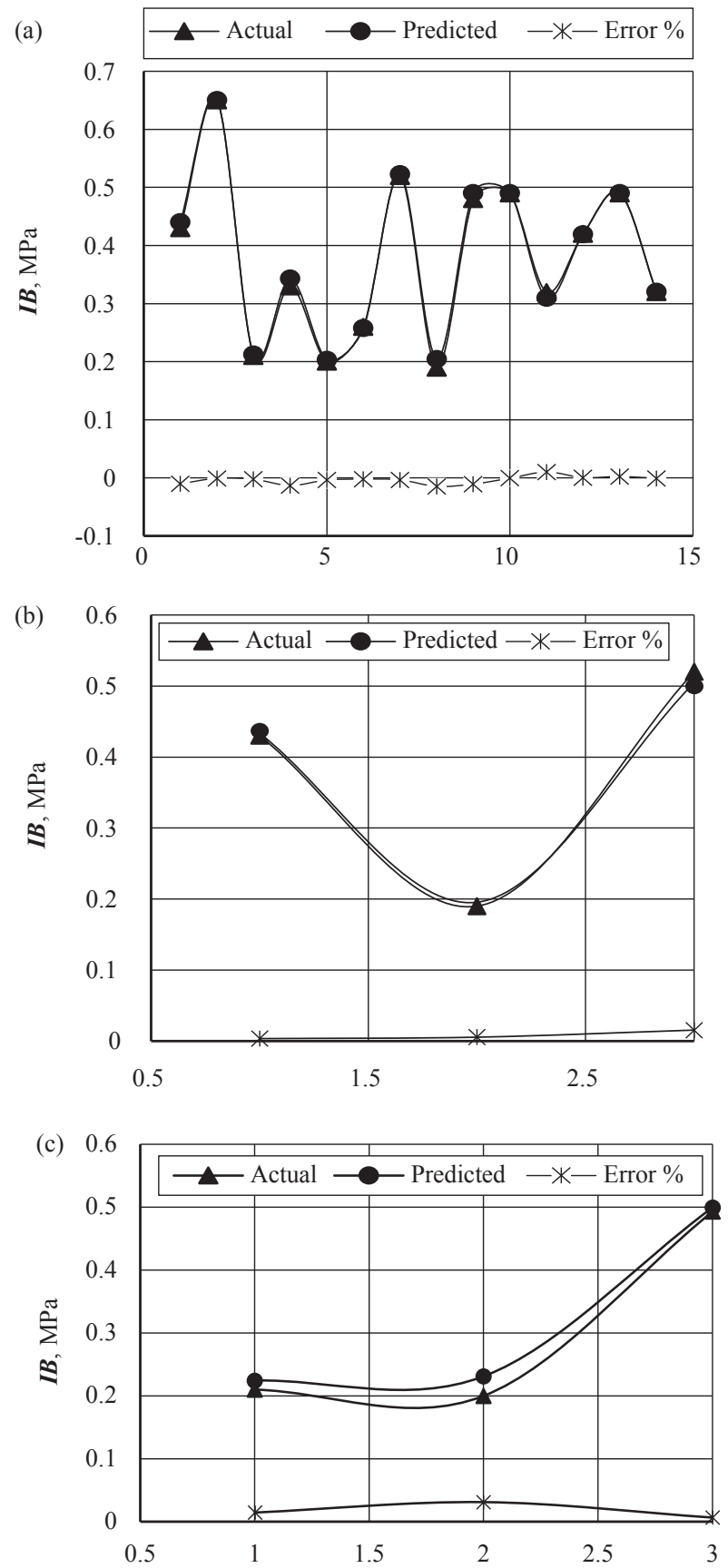

Figure 7 Comparison of actual and model outputs of training (a), validation (b) and testing data (c)

Slika 7. Usporedba stvarnih i modeliranih rezultata (a) treninga, (b) validacije, (c) ispitnih podataka
Besides, in other cases (Figure 10), the particle size was $6 \mathrm{~mm}$, and the nano content and bagasse/reed weight ratio changed. As a result, the predictive changes in the internal bonding for different particle sizes and bagasse/ reed weight ratios are given graphically in Figure 11.

Using the ANN model, it is possible to conceive the relative effect of all selected variables using the contour plots in the 2-D graph. To generate plots and determine the effect of the parameters on the dependent variables, the third variable of each plot is held at the medium value and the other two parameters range from minimum to maximum values. As shown in Figures. 9, 10 and 11, the plots of the suggested model indicated optimum values of the internal bonding as dependent variables for all combinations of the manufacturing parameters with a low deviation.

Figure 9 represents quantitatively the counter plot of the $I B$ developed by the ANN model in an estimated response in the manufacturing process (nano content and particle size) depicted at a fixed bagasse/ reed particle weight ratio. As shown, it is found that the $I B$ was improved up to $0.56 \mathrm{MPa}$ as the nano content increased up to $4.5 \%$ and the particle size ranged from 4.5 to $5.5 \mathrm{~mm}$. This situation can be related to the sufficient amount of the generated $\mathrm{C}-\mathrm{S}-\mathrm{H}$ seeds due to the hydration products grown on their surfaces and the formation of a dense $\mathrm{C}-\mathrm{S}-\mathrm{H}$ gel.

It is well known that silica can effectively increase pozzolanic reaction. Due to the shortage of silica, the cement paste may not be able to drive the pozzolanic reaction sufficiently. During the mixture of water and cement, a high amount of the soluble paste calcium hydroxide $(\mathrm{CH})$ is formed which does not react with any component in the paste and increases the porosity of the cement paste. The solubility of this component of the hydrated cement is high and it increases diffusivity by more than an order of magnitude when it is present in the paste (Bentz and Barboczi, 1992).

Since silica has adequate time to react with calcium hydroxide produced by the hydration of the cement (Chowdhury et al., 2015), the replacement of the cement with enough nanosilica may consume the paste $\mathrm{CH}$ through an early pozzolanic reaction between $\mathrm{CH}$ and surface of nanosilica to form $\mathrm{C}-\mathrm{S}-\mathrm{H}$ seeds, thus significantly lowering the diffusivity (Burris and Riding, 2014). According to this hypothesis, with a higher

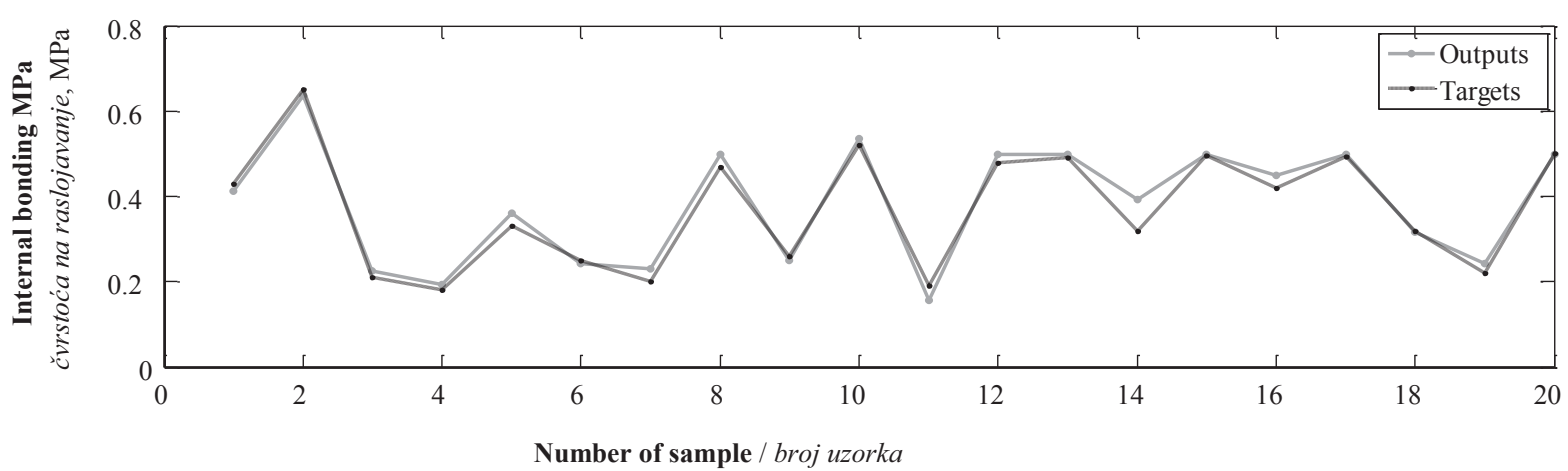

Figure 8 Comparison of actual and model outputs of all data

Slika 8. Usporedba stvarnih i modeliranih rezultata svih podataka 


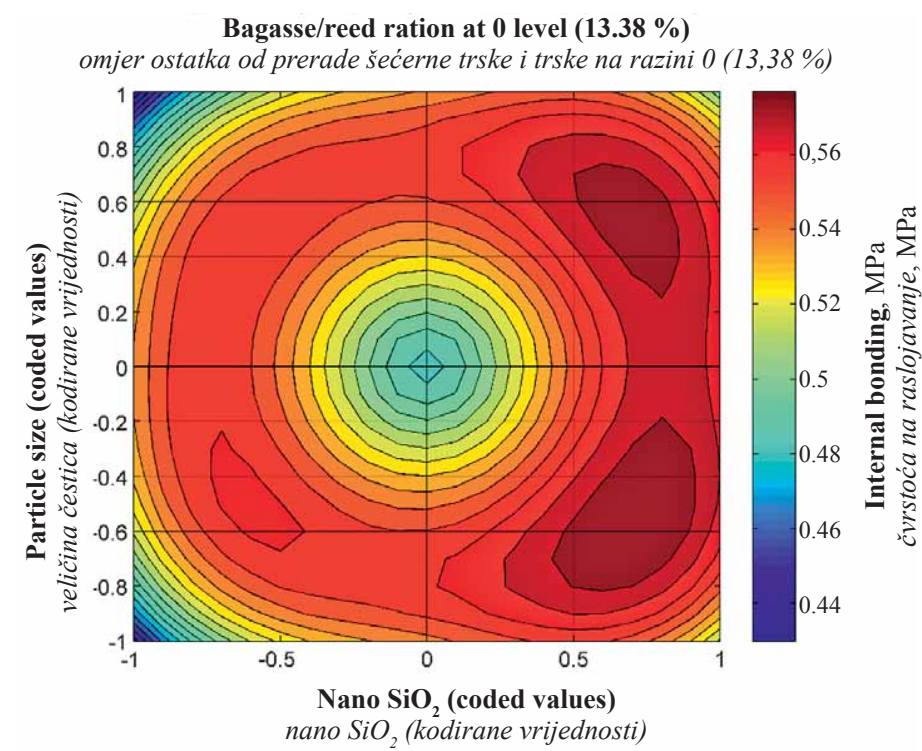

Figure 9 Comparison of actual and model outputs of all data

Slika 9. Usporedba stvarnih i modeliranih rezultata svih podataka

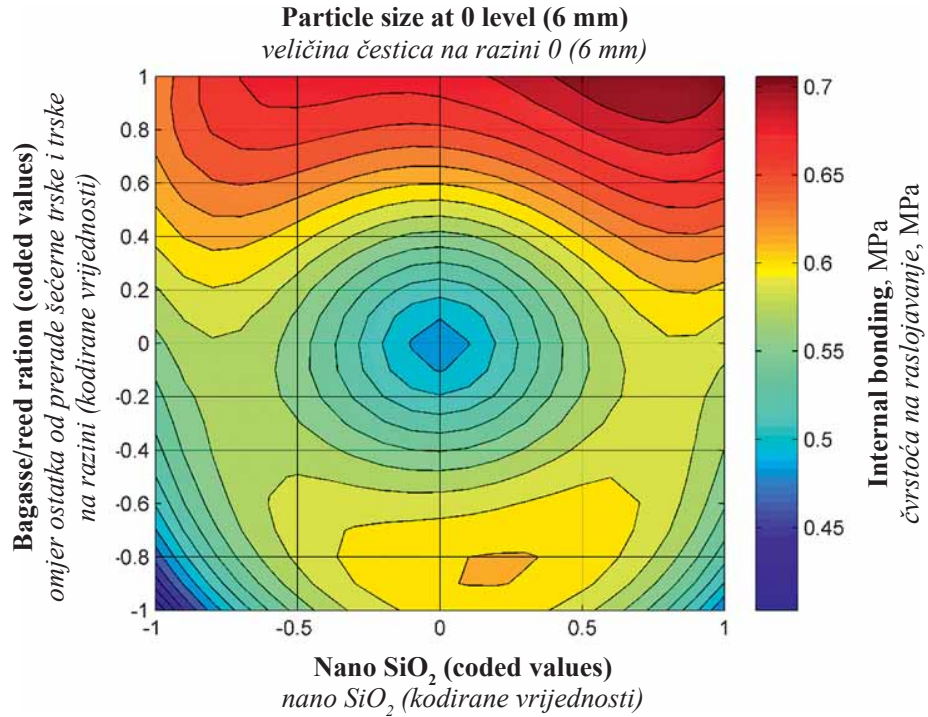

Figure 10 Predictive changes in IB for different nano content and bagasse/reed ratio

Slika 10. Predviđene promjene čvrstoće na raslojavanje za različite sadržaje nanočestica i omjer ostatka od prerade šećerne trske i trske

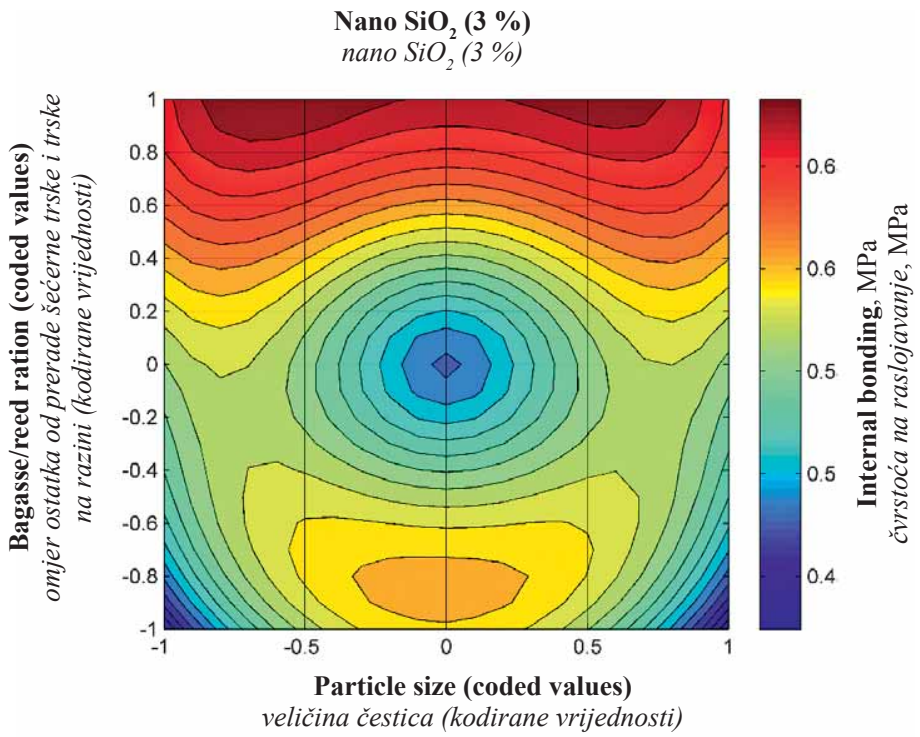

Figure 11 Predictive changes in IB for different particle size and bagasse/reed ratio

Slika 11. Predviđene promjene čvrstoće na raslojavanje za različite veličine čestica i omjer ostatka od prerade šećerne trske $\mathrm{i}$ trske 
amount of nanosilica, a sufficient amount of the generated C-S-H seeds enables the growth of the hydration products on their surfaces and results in the formation of a dense C-S-H gel (Birgisson et al., 2012). This process decreases the $\mathrm{CH}$ content and porosity due to the higher calcium silicate hydrate density resulting from the pozzolanic reaction. Simultaneously, the increase in IB due to nanosilica addition can be related to the formation of less micro- or nanopores in the microstructures of the cement complex through the growth of the silica chains as fillers in C-S-H (Jeffrey et al., 2009). On the other hand, according to $\mathrm{Yu}$ et al., the addition of nanosilica greatly increases the viscosity of the cement-water system, and a large amount of air can be entrapped into the complex, which in turn increases the porosity of the hardened concrete (Yu et al., 2014). However, this statement cannot be true when the microstructure of the panels particles and the space among these particles.

Finer and shorter particles have a higher specific surface area, which can expose more surface to the cement paste with a high $\mathrm{pH}(\approx 12.5)$. Hence, more polysaccharides, mainly hemicelluloses and extractives, can be dissolved in this alkaline solution so that oligoor monosaccharides are formed. These materials (known as poisonous materials) can prevent the nucleation process of C-S-H gel on the grain cement. As C$\mathrm{S}-\mathrm{H}$ seeds increase, the retarding effects of these materials can be neutralized at the time of mixing cement with water and can be reversed by adding supplementary C-S-H after the retarding effect has already been established. The addition of nano $\mathrm{SiO}_{2}$ provides an alternate pathway for increasing the $\mathrm{C}-\mathrm{S}-\mathrm{H}$ content in cement paste and the rate of the hydration process (Rao 2003). At the same time, it reduces the $\mathrm{Ca}(\mathrm{OH})_{2}$ content that cannot drive the pozzolanic reaction, if there is not enough nanosilica.

As it is well known, calcium silicate hydrate (C-S$\mathrm{H})$ and calcium hydroxide $(\mathrm{CH})$ are the main products obtained by the hydration process of the cement paste. Calcium silicate hydrate affects the mechanical properties of the cement paste through the hydration of $\mathrm{C}_{3} \mathrm{~S}$ and $\mathrm{C}_{2} \mathrm{~S}$, while calcium hydrate containing about $20-25 \%$ of the volume of the hydration products does not affect the cementing property. With respect to the morphological properties, calcium hydroxide component is relatively weak and brittle so that the propagation of the cracks under the tensile loading situation can be easily increased through the area enriched by it (Tasdemir et al., 1996). Nanosilica added to the mixture can activate the cement compounds chemically; so reactions are accelerated by calcium hydrates available on the cement paste and calcium silicate hydrate is produced, which enhances the cementitious complex strength.

According to Tasdemir et al. (1996), in the presence of nanosilica, the cracks usually develop through the cement grain. However, in the absence of nanosilica, the cracks usually spread around the coarse grain resulting in a more tortuous fracture path (Norsuraya et al., 2016). This different crack pattern can be attributed to the stronger and more homogeneous interfacial zone as a result of a denser C-S-H formation in the interfacial zone than $\mathrm{CH}$ formation due to the addition of nanosilica.
Generally, many combinations of the studied parameters can be used for predicting $I B$ by the designed model if all outputs are applied. According to Figure 10 , the predictive changes in $I B$ are indicated for nano content and bagasse/reed ratio when the particle size is $>6$ and $<8 \mathrm{~mm}$. The superior $I B$ strength $(>0.7 \mathrm{MPa})$ was predicted at the nano content $>4.5 \%$ and at the bagasse/reed particle weight ratio $>19.81: 80.19$. This can be attributed to the fact that among the agricultural residues, bagasse is one of the herbaceous species with the highest ash and silica content in ash $(\sim 53.10 \%$, Frias and de Rojas, 2013; 59\%, Pilu et al., 2012). However, the amount of ash (6.1\%, Galletti et al., 2015; 3.6-4.2 \%, Spatz et al., 1997) and silica content in ash $(49.4 \%)$ are much lower for reed than for bagasse. Hence, according to the differences between qualitative studies shown in Figures 3, 4 and 5, it can be hypothesized that changing the content of portlandite, ettringite, alite, belite and other compounds produced by hydration process results in variations in the strength, so that raising the pozzolanic reaction in bagasse particles increases the strength of the cement due to the presence of a high level of pozzolanic materials (includes ash, fly ash, condensed silica fume etc.).

The cross-section of reed culms consists of a hypodermal texture with sclerenchyma fibers covered by a very hard, brittle and smooth glossy surface layer and thick parenchyma cells in the inner ring containing a large number of vascular bundles, characterized by heavily lignified bundle sheaths (60), resulting in reinforcement against reversible (elastic) and specially irreversible (plastic) deformation during the cold pressing process of panel manufacturing. On one hand, a drastic increase in the surface smoothness of the reed particles can adversely influence the strength because of the decreased mechanical interlocking between the cement and the particles, and on the other hand, the non-deformability of the reed particles can decrease the contact between particle-cement-particle and increase the empty space between particles.

Furthermore, the value range of the manufacturing variables might give a better understanding to specify the $I B$ with the nano content of $3 \%$ (coded values of 0), the bagasse/reed ratio of 19.81:80.19 and the particle size $>4$ to $<6 \mathrm{~mm}$ (Figure 11). This combination produces panels with the $I B$ values $>0.65 \mathrm{MPa}$. For the present study, it is possible to say that approximately a higher $I B$ value can be obtained with a higher bagasse/ reed ratio. If the model is considered to work with an average error (MAPE) of $1.455 \%$ for the testing data set, this result is acceptable and can be considered as a reasonable outcome.

The panels made from fine particles have structures without any macroscopic empty space in between; meanwhile, the panels prepared with coarser particles consist of structures with empty spaces in between. Basically, this increases the $I B$ strength. However, smaller particles have higher specific surface area. Increasing the surface covered by binder, $I B$ decreases. Hence, despite the largest surface covered by binder in coarser particles on one hand, and the smallest voids within the finer particles on the other hand, the greatest $I B$ strength 
was determined when medium-sized particles were used rather than less coarse particles.

Due to the difference in the cross-section of particles with different sizes, it can be assumed that the $I B$ strength is correlated with the binder penetration in the longitudinal direction of particles and with the amount of the binder on the particle surface, i.e. with the cohesion strength of the bond between the binder and the particles. Fine particles expose higher cross-sectional surface area, so they can absorb more cement paste through the cross-section and also more poisonous component can enter into the solution. These factors decrease the amount of the cement paste on particles and delay the hydration process of the cement paste, and consequently, decrease the cohesion strength. Due to the over-penetration of water into particles, water content in the cement paste is insufficient; hence, cement grains cannot be hydrated completely.

\section{CONCLUSIONS}

4. ZAKLJUČAK

The microstructural compositions of the pure cement pastes, cement paste with $5.5 \%$ hydrated nanosilica, cement paste with $5.5 \%$ nanosilica containing bagasse and cement paste with $5.5 \%$ nanosilica containing reed particles were examined for 15 days using SEM, FTIR and XRD. It is evident from SEM analyses that a large amount of portlandite $\left(\mathrm{Ca}(\mathrm{OH})_{2}\right)$ crystals can be observed as plate-like-hydrates forming a high amount of porosity in the pure cement containing less calcium silicate hydrate (C-S-H), while the addition of nanosilica to the cement paste decreases the $\mathrm{CH}$ crystal formation and increases the density and the compaction structure of other hydration products such as $\mathrm{CSH}$. By adding bagasse or reed particles, the porosity of the hardened cement increases due to the formation of a large amount of air cavities. The addition of nanoparticles can compensate for the negative effect of using lignocellulosic particles in cementitious systems.

According to the results of FTIR and XRD analysis, portlandite, ettringite and C-S-H gels as hydration products increased to a maximum level as nanosilica was added, and the poisonous effect of using lignocellulosic material was compensated by the hydration process of cement paste. However, unhydrated products such as $\mathrm{C} 2 \mathrm{~S}$ and $\mathrm{C} 3 \mathrm{~S}$ increased simultaneously due to the higher hydrophilicity of nanosilica and lignocellulosic particles. It is expected that using a higher level of water can be effective in increasing the hydration products.

The influence of different dosages of nanosilica $(0.45,1.5,3,4.5$, and $5.52 \mathrm{wt} \%)$, particle size of bagasse and reed as lignocellulosic materials ( $2 \mathrm{~mm}$ pass/ 0 on, 4 $\mathrm{mm}$ pass $/ 2 \mathrm{~mm}$ on, $6 \mathrm{~mm}$ pass $/ 4 \mathrm{~mm}$ on, $8 \mathrm{~mm}$ pass $/ 6$ $\mathrm{mm}$ on and $8 \mathrm{~mm}$ on) and different weight ratios of bagasse to reed particles $(2.55: 97.45,6.94: 93.06$, $13.38: 86.62,19.81: 80.19$ and $24.20: 75.80)$ on the internal bonding strength of the cement-bonded particleboard was studied using ANN. The maximum internal bonding strength of $0.60 \mathrm{MPa}$ is exhibited by cement-bonded par- ticleboards manufactured with the optimized parameters including the nanosilica content of $3.5 \%$, the particle size of $5.5 \mathrm{~mm}$ and the bagasse:reed ratio of 19.81:80.19.

The effect of the bagasse:reed ratio on the $I B$ of the CBPB is more than that of nanosilica and particle size. The acceptable predictions of the observed CBPB internal bonding by the model indicate that ANNs can be a favorable tool for understanding those complexes. Consequently, the model can be used by producers to choose the internal bonding optimally as an important function of the measured properties of the cementbonded lignocellulosic panels.

\section{Acknowledgements - Zahvala}

The authors are thankful to the Department of Wood and Paper Science and Technology and Natural Resources College, University of Zabol, Iran, for obtaining and providing the database used in the paper.

\section{REFERENCES}

5. LITERATURA

1. Akyuz, I.; Ozsahin, S.; Tiryaki, S.; Aydin, A., 2017: An application of artificial neural networks for modeling formaldehyde emission based on process parameters in particleboard manufacturing process. Clean Technologies and Environmental Policy 19: 1449-1458.

https://doi.org/10.1007/s10098-017-1342-0.

2. Anjos, R. D.; Ismael, M. R.; Oliveria, I. R.; Pandolfelli, V. C., 2008: Workability and setting parameters evolution of colloidal silica bonded refractory suspension. Ceramics International, 34 (1): 165-171.

https://doi.org/10.1016/j.ceramint.2006.09.004.

3. Arsene, M.; Okwo, A.; Bilba, K.; Soboyejo, A.; Soboyejo, A. B. O., 2007: Chemically and thermally treated vegetable fibers for reinforcement of cement-based composites. Materials and Manufacturing Processes, 22 (2): 214-227. https://doi.org/10.1080/10426910601063386.

4. Bektas, I.; Guler, C.; Kalaycioglu, H.; Mengenoglu, F.; Nacar, M., 2005: The manufacture of particleboards using sunflower stalks (Helianthusannuus I.) and poplar wood (Populus alba L.). Journal of Composite Materials, 39 (5): 467-473.

https://doi.org/10.1177/0021998305047098.

5. Bentz, D. P.; Barboczi, E. J., 1992: Modelling the leaching of calcium hydroxide from cement paste: Effect of pore space percolation and diffusivity. Materials and Structures, 25 (9): 523-533. https://doi.org/10.1007/BF02472448.

6. Bilba, K.; Arsene, M. A.; Ouensanga, A., 2003: Sugar cane bagasse fiber reinforced cement composites. Part I: Influence of the botanical components of bagasse on the setting of bagasse/cement composite. Cement and Concrete Composites, 25 (1): 91-96. https://doi.org/10.1016/S0958-9465(02)00003-3.

7. Birgisson, B.; Mukhopadhyay, A. K.; Geary, G.; Khan, M.; Sobolev, K., 2012: Nanotechnology in concrete materials; A Synopsis', Transportation Research Circular E-C170, Task Force on Nano technology - Based Concrete Materials Transportation Research Board, 2012, pp. 1-27.

8. Bjornstrom, J.; Martinelli, A.; Matic, A.; Borjesson, L.; Panas, I., 2004: Accelerating effects of colloidal nanosilica for beneficial calcium-silicate-hydrate formation in cement. Chemical Physics Letters, 392 (1-3): 242-248. https://doi.org/10.1016/j.cplett.2004.05.071. 
9. Burris, L. E.; Riding, K. A., 2014: Diffusivity of binary and ternary concrete mixture blends. Aci Materials Journal, 111 (4): 373-382. https://doi.org/10.14359/51686826.

10. Chang, C. F.; Chen, J. W., 2006: The experimental investigation of concrete carbonation depth. Cement and Concrete Research, 36 (9): 1760-1767.

https://doi.org/10.1016/j.cemconres.2004.07.025.

11. Chowdhury, S.; Mishra, M.; Suganya, O., 2015: The incorporation of wood waste ash as a partial cement replacement material for making structural grade concrete: An overview. Ain Shams Engineering Journal, 6 (2): 429-437. https://doi.org/10.1016/j.asej.2014.11.005.

12. Coatanlem, P.; Jauberthie, R.; Rendell, F., 2006: Lightweight wood chipping concrete durability. Construction and Building Materials, 20 (9): 776-781. https://doi. org/10.1016/j.conbuildmat.2005.01.057.

13. Cook, D. F.; Chiu, C. C., 1997: Predicting the internal bond strength of particleboard, utilizing a radial basis function neural network. Engineering Application of Artificial Intelligence, 10 (2): 171-177. https://doi. org/10.1016/S0952-1976(96)00068-1.

14. Cook, D. F.; Ragsdale, C. T.; Major, R. L., 2000: Combining a neural network with a genetic algorithm for process parameter optimization. Engineering Application of Artificial Intelligence, 13 (4): 391-396. https://doi.org/10.1016/S0952-1976(00)00021-X.

15. Cook, D. F.; Whittaker, A. D., 1992: Neural network models for prediction of process parameters in wood products manufacturing. In: Proceedings of the $1^{\text {st }}$ industrial engineering research conference, Chicago (IL), May 1992, pp. 209-211.

16. Desai, K. M.; Survase, S. A.; Saudagar, P. S.; Lele, S. S.; Singhal, R. S: 2008: Comparison of artificial neural network (ANN) and response surface methodology (RSM) infermentation media optimization: case study of fermentative production of scleroglucan. Biochemical Engineering Journal, 41 (3): 266-273.

https://doi.org/10.1016/j.bej.2008.05.009.

17. Eslah, F.; Enayati, A. A.; Tajvidi, M.; Faezipour, M. M., 2012: Regression models for the prediction of poplar particleboard properties based on urea formaldehyde resin content and board density. Journal of Agricultural Science and Technology, 14 (6): 1321-1329.

18. Eusebio, D. A., 2004: Manufacturing parameters on the properties of cement-bonded boards using sugarcane baggase. In: Proceedings of International conference on environmentally-compatible forest products ICECFOP1. Oporto, Portugal, 22-24 September 2004, pp. 149-160.

19. Fernandez, F. G.; Esteban, L. G.; de Palacios, P.; Navarro, N.; Conde, M., 2008: Prediction of standard particleboard mechanical properties utilizing an artificial neural network and subsequent comparison with a multivariate regression model. Forest Systems, 17 (2): 178-187. https://doi.org/10.5424/srf/2008172-01033.

20. Fernandez-Carrasco, L.; Vazquez, E., 2009: Reactions of fly ash with calcium aluminate cement and calcium sulphate. Fuel, 88 (9): 1533-1538. https://doi.org/10.1016/j.fuel.2009.02.018.

21. Filho, R. D. T.; Ghavami, K.; England, G. L.; Scrivener, K., 2003: Development of vegetable fibre-mortar composites of improved durability. Cement Concrete Composite, 25 (2): 185-196. https://doi.org/10.1016/S0958-9465(02)00018-5.

22. Frias, M.; de Rojas, M. S., 2013: Artificial pozzolans in eco-efficient. In: Pacheco-Togal, F., Jalali, S., Labrincha, J., John, V. M. (eds.), Eco-efficient Concrete. Woodhead Publishing Limited, Cambridge, pp. 105-122.

23. Galletti, A. M. R.; D'Alessio, A.; Licursi, D.; Antonetti, C.; Valentini, G.; Galia, A.; Di Nasso, N. N., 2015:
Midinfrared FT-IR as a tool for monitoring herbaceous biomass composition and its conversion to furfural. Journal of Spectroscopy, ID 719042.

https://doi.org/10.1155/2015/719042.

24. Gurgen, A.; Ustaomer, D.; Yildiz, S., 2019: Application of artificial neural network to predict the effect of paraffin addition on water absorption and thickness swelling of MDF. Drvna industrija, 70 (3): 247-255. https://doi.org/10.5552/drvind.2019.1839.

25. Innocentini, M. D. M.; Pardo, A. R. F.; Pandolfelli, V. C., 2002: Permeability of high- alumina refractory castables based on various hydraulic binders. Journal of the American Ceramic Society, 85 (6): 1517-1521. https://doi.org/10.1111/j.1151-2916.2002.tb00306.x.

26. Jeffrey, J. T.; Hamlin, M. J.; Jeffrey, J. J., 2009: Influence of nucleation seeding on the hydration mechanisms of tricalcium silicate and cement. The Journal of Physical Chemistry C, 113: 4327-4334. https://doi.org/10.1021/jp809811w.

27. Jennings, H. M.; Thomas, J. J.; Gevrenov, J. S.; Constantinides, G.; Ulm, F. J., 2007: A multi-technique investigation of the nanoporosity of cement paste. Cement and Concrete Research, 37 (3): 329-336.

https://doi.org/10.1016/j.cemconres.2006.03.021.

28. Juarez, C.; Duran, A.; Valdez, P.; Fajardo, G., 2007: Performance of "Agave lecheguilla" natural fiber in Portland cement composite exposed to severe environment conditions. Building and Environment, 42 (3): 1151-1157. https://doi.org/10.1016/j.buildenv.2005.12.005.

29. Kim, J. J.; Fan, T.; Taha, M. M. R., 2010: Homogenization model examining the effect of nanosilica on concrete strength and stiffness. Transportation Research Record Journal of the Transportation Research Board, 2141 (1): 28-35. https://doi.org/10.3141/2141-06.

30. Kontoleontos, F.; Tsakiridis, P. E.; Marinos, A.; Kaloidas, V.; Katsioti, M., 2012: Influence of colloidal nanosilica on ultrafine cement hydration: Physicochemical and microstructural characterization. Construction and Building Materials, 35: 347-360.

https://doi.org/10.1016/j.conbuildmat.2012.04.022.

31. Korai, H.; Watanabe, K., 2016: Predicting the strength reduction of particleboard subjected to various climatic conditions in Japan using artificial neural networks. European Journal of Wood and Wood Products, 75: 385396. https://doi.org/10.1007/s00107-016-1056-8.

32. Lavergne, F.; Belhadi, R.; Carriat, J.; Ben Fraj, A., 2019: Effect of nanosilica particles on the hydration, the rheology and the strength development of a blended cement paste. Cement and Concrete Composites, 95: 42-55. https://doi.org/10.1016/j.cemconcomp.2018.10.007.

33. Lowe, S.; Browne, M.; Boudjelas, S.; De Poorter, M., 2000: 100 of the world's worst invasive alien species - a selection from the Global Invasive Species Database. Invasive Species Specialist Group, World Conservation Union.

34. Maddalena, R.; Hall, C.; Hamilton, A., 2019: Effect of silica particle size on the formation of calcium silicate hydrate $[\mathrm{C}-\mathrm{SH}]$ using thermal analysis. Thermochimica Acta, 672: 142-149. https://doi.org/10.1016/j.tca.2018.09.003.

35. Mondal, P.; Shah, S. P.; Marks, L. D.; Gaitero, J. J., 2010: Comparative study of the effects of microsilica and nanosilica in concrete. Transportation Research Record: Journal of the Transportation Research Board, 2141 (1): 6-9. https://doi.org/10.3141/2141-02.

36. Nakanishi, E. Y.; Frías, M.; Santos, S. F.; Rodrigues, M. S.; Villa, R. V.; Rodriguez, O.; Junior, H. S., 2016: Investigating the possible usage of elephant grass ash to manu- 
facture the eco-friendly binary cements. Journal of Cleaner Production, 116 (10): 236-243. https://doi.org/10.1016/j.jclepro.2015.12.113.

37. Nazerian, M.; Nanaii, H. S.; Gargarii, R. M., 2018: Influence of Nano-Silica $\left(\mathrm{SiO}_{2}\right)$ content on mechanical properties of cement-bonded particleboard manufactured from lignocellulosic materials. Drvna industrija, 69 (4): 317-328. https://doi.org/10.5552/drind.2018.1758.

38. Nemli, G.; Demirel, S.; Gümüokaya, E.; Aslan, M.; Acar, C., 2009: Feasibility of incorporating waste grass clippings (Lolium perenne L.) in particleboard composites. Waste Management, 29 (3): 1129-1131. https://doi.org/10.1016/j.wasman.2008.07.011.

39. Norsuraya, S.; Fazlena, H.; Norhasyimi, R., 2016: Sugarcane bagasse as a renewable source of silica to synthesize Santa Barbara amorphous-15 (SBA-15). Proccedia Engineering, 148: 839-846.

https://doi.org/10.1016/j.proeng.2016.06.627.

40. Ozsahin, S., 2013: Optimization of process parameters in oriented strand board manufacturing with artificial neural network analysis. European Journal of Wood and Wood Products, 71: 769-777. https://doi.org/10.1007/s00107-013-0737-9.

41. Pilu, R. Bucci, A. Badone, F. C.; Landoni, M., 2012: Giant reed (Arundo donax L.): A weed plant or a promising energy crop? African Journal of Biotechnology, 11 (38): 9163-9174. https://doi.org/10.5897/AJB11.4182.

42. Quinn, L. D.; Holt, J. S., 2008: Ecological correlates of invasion by Arundo donax in three southern California riparian habitats. Biological Invasions, 10 (5): 591-601. https://doi.org/10.1007/s10530-007-9155-4.

43. Raiess Ghasemi, A. M.; Parhizkar, T.; Ramezanianpour, A. A., 2010: Influence of colloidal nano- $\mathrm{SiO}_{2}$ addition as silica fume replacement material in properties of concrete. In: Proceeding of the second international conference on sustainable construction materials and technologies, Ancona, 28-30 June 2010, pp. 1-8.

44. Rao, G. A., 2003: Investigations on the performance of silica fume-incorporated cement pastes and mortars. Cement and Concrete Research, 33: 1765-1770. https://doi.org/10.1016/S0008-8846(03)00171-6.

45. Rupasinghe, M.; Nicolas, R. S.; Mendis, P.; Sofi, M.; Ngo, T., 2017: Investigation of strength and hydration characteristics in nanosilica incorporated cement paste. Cement and Concrete Composites, 80: 17-30. https://doi. org/10.1016/j.cemconcomp.2017.02.011.

46. Sedan, D.; Pagnoux, C.; Smith, A.; Chotard, T., 2008: Mechanical properties of hemp fibre reinforced cement: influence of the fibre/matrix interaction. Journal of the European Ceramic Society, 2 (1): 183-192. https://doi.org/10.1016/j.jeurceramsoc.2007.05.019.

47. Shenk, J. S.; Westerhaus, M. O., 1996: Calibration the ISI way. In: Near infrared spectroscopy: the future waves (Davies, A. M. C.; Williams, P., eds.). NIR Publications, Chichester, UK, pp. 198-202.

48. Singh, L. P.; Goel, A.; Bhattacharyya, S. K.; Mishra, G., 2016: Quantification of hydration products in cementitious materials incorporating silica nanoparticles. Frontiers of Structural and Civil Engineering, 10 (2), 162167. https://doi.org/10.1007/s11709-015-0315-9.

49. Spatz, H. C.; Beismann, H.; Bruchert, F.; Emanns, A.; Speck, T., 1997: Biomechanics of the giant reed Arundo donax. Philosophical Transactions of the Royal Society B, 352 (1349): 1-10. https://doi.org/10.1098/rstb.1997.0001.

50. Stutzman, P. E.; Feng, P.; Bullard, J. W., 2016: Phase Analysis of Portland cement by Combined Quantitative X-Ray Powder Diffraction and Scanning Electron Mi- croscopy. Journal of Research of the National Institute of Standards and Technology, 121: 47-107.

https://doi.org/10.6028/jres.121.004.

51. Tasdemir, C.; Tasdemir, M. A.; Lydon, F. D.; Barr, B. I. G., 1996: Effects of silica fume and aggregate size on the brittleness of concrete. Cement and Concrete Research, 26 (1): 63-68.

https://doi.org/10.1016/0008-8846(95)00180-8.

52. Tiryaki, S.; Ozsahin, S.; Yildirim, I., 2014: Comparison of artificial neural network and multiple linear regression models to predict optimum bonding strength of heat treated woods. International Journal of Adhesion and Adhesives, 55: 29-36. https://doi.org/10.1016/j.ijadhadh.2014.07.005.

53. Troedec, M. L.; Dalmay, P.; Patapy, C.; Peyratout, C.; Smith, A.; Chotard, T., 2011: Mechanical properties of hemp lime reinforced mortars: influence of chemical treatment of fibers. Journal of Composite Materials, 45 (22): 2347-2357. https://doi. org/10.1177/0021998311401088.

54. Watanabe, K.; Korai, H.; Matsushita, Y.; Hayashi, T., 2015: Predicting internal bond strength of particleboard under outdoor exposure based on climate data: comparison of multiple linear regression and artificial neural network. Journal of Wood Science, 61: 151-158. https://doi.org/10.1007/s10086-014-1446-7.

55. Wei, Y. M.; Tomita, M.; Hiramatsu, Y.; Miyatake, A.; Fujii, T.; Fujii, T.; Yoshinaga, S., 2003: Hydration behavior and compressive strength of cement mixed with exploded wood fiber strand obtained by the water-vapor explosion process. Journal of Wood Science, 49 (4): 317-326. https://doi.org/10.1007/s10086-002-0479-5.

56. Xie, X.; Gou, G.; Wei, X.; Zhou, Z.; Jiang, M.; Xu, X.; Wang, Z.; Hui, D., 2016: Influence of pretreatment of rice straw on hydration of straw fiber filled cement based composites. Constriction and Building Materials, 113: 449-455.

https://doi.org/10.1016/j.conbuildmat.2016.03.088.

57. Xu, P.; Kirkpatrick, R. J.; Poe, B.; McMillan, P. F.; Cong, X., 1999: Structure of calcium silicate hydrate (C-S-H): near-, mid-, and far-infrared spectroscopy. Journal of the American Ceramic Society, 82 (3): 742-748. https://doi.org/10.1111/j.1151-2916.1999.tb01826.x.

58. Y1lmaz, B.; Olgun, A., 2008: Studies on cement and mortar containing low-calcium fly ash, limestone, and dolomitic limestone. Cement and Concrete Composites, 30 (3): 194-201. https://doi.org/10.1016/j.cemconcomp.2007.07.002.

59. Yu, R.; Spiesz, P.; Brouwers, H. J. H., 2014: Effect of nanosilica on the hydration and microstructure development of ultra-high performance concrete (UHPC) with a low binder amount. Constriction and Building Materials, 65 (29): 140-150. https://doi.org/10.1016/j.conbuildmat.2014.04.063.

60. Zhang, G.; Ptuwo, B. E.; Hu, M. Y., 1998: Forecasting with artificial neural network: the state of the art. International Journal of Forecasting, 14 (1): 35-62. https://doi.org/10.1016/S0169-2070(97)00044-7.

\author{
Corresponding address: \\ MORTEZA NAZERIAN \\ Shahid Beheshti University \\ Faculty of New technologies Engineering \\ Department of BioSystems \\ Tehran, IRAN \\ e-mail: morteza17172000@yahoo.com
}

